\title{
Can Joe the Plumber Support Redistribution? Law, Social Preferences, and Sustainable Policy Design
}

\author{
GILLIAN LESTER*
}

\section{INTRODUCtION}

How does one win popular support for laws designed specifically to redistribute economic wealth? One can hardly gainsay that this is aperhaps the-defining issue for domestic policy in the age of President Obama. Even as the recent financial crisis has exposed the need for a reliable social safety net, attempts to respond through the political and legislative arenas have triggered increasingly hostile responses among conservatives, populists, Massachusetts voters, and incipient tea partiers. ${ }^{1}$ The puzzle of how to attract and preserve public support for law reform aimed at redistribution - of both income and risk-is of no small significance at this critical juncture of unsettled public sentiment and a motivated (though perhaps increasingly reticent) presidential administration.

If this is an issue for the moment, however, it is also an issue for the ages. Public debates have always been particularly contentious when they involve redistributional social policy. The questions of how to spread social risks and who should receive state largesse have, to cite

* Professor of Law, U.C. Berkeley School of Law. For helpful suggestions, I am grateful to Anne Alstott, Scott Altman, Bobby Bartlett, Matthew Dimick, Dan Farber, Chai Feldblum, Alan Galloway, David Gamage, Andrew Guzman, Jon Hansen, Allison Hoffman, Dan Kahan, Greg Keating, Mark Kelman, Randall Kennedy, David Kirp, Chris Kutz, Adriaan Lanni, Bill Lester, Katerina Linos, Richard McAdams, Martha Minow, Sachin Pandya, Katherine Porter, Ezra Rosser, Jeff Selbin, Vicki Schultz, Michael Shapiro, Seana Shiffrin, Bill Simon, Sarah Song, James Spindler, Steve Sugarman, Kirk Stark, Lior Strahilevitz, Eric Talley, Lucie White, and workshop participants at Berkeley, Chicago, Connecticut, Harvard, Minnesota, Tel Aviv, Toronto, USC, and Yale Law Schools and the Radcliffe Institute for Advanced Study. Able research assistance was provided by Jack Jackson, Jonah Lalas, and Elizabeth Ryan. For research support I wish to thank U.C. Berkeley School of Law, as well as Harvard Law School, where I was Sidley Austin Visiting Professor of Law during the 2008-2009 academic year.

1 E.g., Michael Luo, Kim Severson, David Herszenhorn \& Robbie Brown, Millions Bracing for Cutoff of Unemployment Checks, N.Y. Times, Dec. 4, 2010, at A11 (discussing the partisan gridlock in extending long-term unemployment benefits). 
just a few recent examples, fueled controversies over whether national health care reform ought to incorporate means testing, that is, targeted transfers based on low income or means, ${ }^{2}$ as well as sharp disagreements over expansions of Medicaid, the federal program that supplies health insurance to low-income Americans, ${ }^{3}$ and the Children's Health Insurance Program (CHIP), the federal program that subsidizes health insurance for the children of low-income families. ${ }^{4}$

In recent years, a number of scholars from law and the social sciences have advocated expanding social insurance and other aspects of the "social safety net," with particular attention to the needs of lowincome citizens. ${ }^{5}$ Much academic work offers compelling normative arguments for intervention, paired with proposals for law reform. Nevertheless, the strikingly slow progress of redistributional law re-

2 See, e.g., Shailagh Murray, Democrats Stung by Dissenters: Unity on Agenda Eludes Party Leaders, Wash. Post, Mar. 10, 2009, at A1 (mentioning recent debates over whether Medicare drug benefits ought to be means-tested); John Aloysius Farrell, Obama Hides Medicare Means-Testing in Plain Sight--In his Big Budget, U.S. News \& World Rep., Thomas Jefferson Street Blog (Mar. 9, 2009), http://www.usnews.com/opinion/blogs/johnfarrell/2009/3/9/obama-hides-medicare-means-testing-in-plain-sight-in-his-big-budget. $\mathrm{html}$.

${ }^{3}$ See, e.g., Jim Angle, Health Care Bill Would Strain States by Expanding Medicaid, Analysts Say, FoxNews.com (Mar. 20, 2010), available at http://www.foxnews.com/politics/ 2010/03/20/health-care-strain-states-expanding-medicaid-analysts-say (discussing opposition to an element of health care reform that would expand Medicaid); Editorial, Health Reform, the States and Medicaid, N.Y. Times, Jan. 10, 2010, at WK9 (supporting Medicaid expansion); see also Jeffrey L. Soltermann, Medicaid and the Middle Class: Should the Government Pay for Everyone's Long-Term Health Care?, 1 Elder L.J. 251 (1993).

${ }^{4}$ See, e.g., Jon Ward, Bush Vetoes SCHIP Expansion; Democrats Rally Against "Heartless" Step, Wash. Times, Oct. 4, 2007, at A4 (emphasizing deep ideological divide between President Bush and Senator Obama with respect to a Democratic bill to increase federal outlays on SCHIP by roughly $\$ 30$ billion, with Bush explaining that "[the Democrats'] proposal would result in taking a program meant to help poor children and turning it into one that covers children in households with incomes of up to $\$ 83,000$ a year," and Obama responding that Washington's failure shows "a callousness of priorities that is offensive to the ideals we hold as Americans"). (The program was formerly known as the State Children's Health Insurance Program (SCHIP)). The Obama Administration made restoration of the bill an early legislative priority. See Brian Montopoli, Obama Signs Kids Health Insurance Bill, Political Hotsheet (Feb. 4, 2009, 5:18 PM), http://www.cbsnews.com/8301503544_162-4776308-503544.html (bill authorized spending an added $\$ 32.8$ billion to expand the health coverage program to include about four million more children).

5 E.g., Michael J. Graetz \& Jerry L. Mashaw, True Security: Rethinking American Social Insurance 281-305 (1999) (developing a proposal for comprehensive reform of social provisions using a social insurance model); Jacob S. Hacker, The Great Risk Shift: The Assault on American Jobs, Families, Health Care, and Retirement and How You Can Fight Back 182-91 (2006) (advocating stronger social protection through a combination of stateprovided social insurance and employer mandates); Katherine V.W. Stone, From Widgets to Digits: Employment Regulation for the Changing Workplace 243-57 (2004) (describing changes in the traditional career model of employment and accompanying "[c]ollapse of the [p]rivate [w]elfare [s]tate"); David Charny, The Employee Welfare State in Transition, 74 Tex. L. Rev. 1601, 1636-43 (1996) (arguing for collectivization of risk through publicbased social insurance pools). 
form during Obama's early years in office suggests that advocates of such initiatives failed to attend to more practical questions of how redistributional policies can garner and retain robust public support, particularly when perceived to redirect resources away from politically-engaged individuals who fear they will emerge economically worse off (embodied canonically by Joe the Plumber in the 2008 election) ${ }^{6}$

This Article aims to help provide those pragmatic insights. In particular, it analyzes and compares law reforms that purport to redistribute by targeting benefits at poor individuals through an income or means test, with those that rely more heavily on "universally" allocated benefits, not conditioned on poverty. I argue that, notwithstanding its more muted effects in the short run, universalist policies may be more effective at achieving redistribution in the long run due to greater political durability, and--more intriguingly--by catalyzing social toleration for redistribution. I support this argument by drawing on the growing body of research in psychology and economics suggesting that people have a mixture of self-regarding and otherregarding impulses, and that some forms of social organization are more likely than others to elicit pro-social behavior. Universalist programs, I argue, plausibly increase political support for redistribution by tapping social norms of reciprocity, generating group identity effects based on a sense of common vulnerability, and serving as a "policy frame" that de-emphasizes the salience of low-income people as an undeserving "out-group." I use a case study of recent social insurance legislation as a springboard for developing an empirical research agenda that will help evaluate the strength of this thesis. I further speculate on whether universal welfare institutions may lead to a kind of "social learning" that fosters toleration for redistribution in a deeper way over time.

Although a great deal of legal scholarship concerns itself with questions of inequality and redistribution, the legal academy has largely overlooked the question of means testing versus universalism. This is so notwithstanding that it is a key lever of institutional design and an issue that has long consumed the attention of political scientists, econ-

6 Joe the Plumber was a moniker that the McCain-Palin campaign bestowed on Joseph Wurzelbacher, who famously confronted Barack Obama during the 2008 presidential campaign about the perceived deleterious effects that Obama's tax policy would have on his business. See Larry Rohter, Plumber from Ohio Is Thrust into Spotlight, N.Y. Times, Oct. 16,2008 , at A27. Interestingly, it appeared that Wurzelbacher would likely have been a net beneficiary of the proposed Obama tax plan. See id.

Although the focus of this Article is support by the mass public, other kinds of political constraint are also very significant--for example, support by businesses on whom regulations might be imposed, or insurers concerned about their product being crowded out by state provision. 
omists, and public policy experts. This Article tries to correct this lacuna by analyzing, in depth and from an interdisciplinary perspective, this policy device that ought to command a key place in the toolkit of legal scholars and law reformers.

A second contribution of this Article is at the level of theory. Recent years have seen a surge of interest among legal scholars in social cooperation, particularly in the study of the Internet, ${ }^{7}$ and the behavioral and cultural mechanisms by which social preferences evolve or can be "nudged." 8 Although existing legal scholarship has begun to explore applications of these insights, their theoretical development and policy extensions are far from exhausted. This Article aims both to extend the grasp of our theoretical understanding of social psychology, social cooperation, and law, and also to extend current legal scholarship into a new legal arena, that of reforming the social safety net. As such, it contributes to a lively and growing discourse within legal scholarship pertaining not only to distributive justice and social welfare law, but also to tax policy, public finance, legislation, health law, environmental law, work law, and administrative law.

Third, this Article forms part of a larger project that aims to reorient the legal study of social welfare programs to account for the political impact of legal design. Legal scholarship on problems of distributive justice has a tendency-understandably, given the challenges of doing careful theoretical work-to stop short of tackling questions of political feasibility. A familiar refrain-one I myself have invoked in prior work -is to identify questions of feasibility as "beyond the scope of this article," or "a task for political actors." This Article aims less to retrace the normative case for redistribution than to make the case that such an endeavor cannot stand wholly apart from pragmatic challenges of cultivating political support and sustainability. Thus my Article may be of interest to, for example, those who have followed debates over whether redistribution is most efficiently achieved through the income tax or legal rules, not because it chooses a winner, but because it stresses the additional relevance of how choice of institution might influence social preferences regarding redistribution. ${ }^{9}$

7 E.g., Yochai Benkler, The Wealth of Networks: How Social Production Transforms Markets and Freedom (2006).

8 E.g., Richard H. Thaler \& Cass R. Sunstein, Nudge: Improving Decisions About Health, Wealth, and Happiness (2008); Dan M. Kahan \& Donald Braman, Cultural Cognition and Public Policy, 24 Yale L. \& Pol'y Rev. 149 (2006).

9 See, e.g., Steven Shavell, A Note on Efficiency vs. Distributional Equity in Legal Rulemaking: Should Distributional Equity Matter Given Optimal Income Taxation?, 71 Am. Econ. Rev. (Papers \& Proc.) 414 (1981); Louis Kaplow \& Steven Shavell, Why the Legal System Is Less Efficient than the Income Tax in Redistributing Income, $23 \mathrm{~J}$. Legal 
This Article, through analysis and illustration, invites legal scholars to make use of what social scientists have to say about the emergence and evolution of social preferences and develop a scholarly, well-informed approach to sustainable legal reform. Understanding the role that social cooperation can play in building politically sustainable redistributive programs is important, timely, and critical.

From the standpoint of efficacy, the contest between means testing and universalism as instruments of redistribution would seem to be over before it has begun. Means testing is, both on its face and by design, the most direct and administratively efficient way to redistribute resources. Some have argued, however, that universal forms of provision might actually be more effective in achieving meaningful redistribution. The "paradox of redistribution" theory posits that regimes with more universal provision across economic groups may achieve greater redistribution and poverty reduction in the long run because they generate more political support. ${ }^{10}$ There are a number of reasons to think this theory is plausible.

"Middle-class"11 beneficiaries of a universalist regime might, of course, exert their political influence on the administration of universal programs to favor the well-off at the expense of the less well-off. ${ }^{12}$ Nevertheless, universal provision might still achieve more redistribution than means testing because improvements that benefit the middle class will in some instances improve the lot of everyone. Some years ago, a co-author and I critically evaluated special education reforms in U.S. public education. ${ }^{13}$ Part of our argument was that middle-class parents have used their sharp elbows and political clout to direct edu-

Stud. 667 (1994); Chris William Sanchirico, Taxes Versus Legal Rules as Instruments for Equity: A More Equitable View, 29 J. Legal Stud. 797 (2000).

10 Walter Korpi \& Joakim Palme, The Paradox of Redistribution and Strategies of Equality: Welfare State Institutions, Inequality, and Poverty in the Western Countries, 63 Am. Soc. Rev. 661, 681-82 (1998).

11 This term often remains undefined in discourse about means testing and universalism, although typically it is used simply to denote those who are in the middle range of the income distribution and whose income falls above the cut-off point for means-tested benefits. For present purposes, I also use the term in this shorthand way, although it bears emphasis that there are very difficult conceptual and empirical questions in defining the "middle class," for example, whether it should be culturally, educationally, occupationally, or economically defined, whether a sharp line can be drawn between it and adjacent "classes," and so on.

12 For an illustration of this perspective in the legal literature, see, e.g., George J. Stigler, Director's Law of Public Income Redistribution, 13 J. Law \& Econ. 1 (1970).

13 Mark Kelman \& Gillian Lester, Jumping the Queue: An Inquiry into the Legal Treatment of Students with Learning Disabilities (1997). 
cational resources towards their own children. ${ }^{14}$ Nonetheless, it seems plain that whether or not it was largely self-interested, that advocacy effort on the part of middle-class parents succeeded in profoundly increasing public resources-relative to the status quo ante-directed toward all children with disabilities, even if not in equal measure..$^{15}$

Second, universal provision might increase redistribution by "beneficially" crowding out a system of private and quasi-private welfare provision that increases economic inequality. Even if universal programs facially redistribute less efficiently than means-tested programs, in the aggregate they may do a better job because some redistribution through a universal program is better than no redistribution at all.

Third, and perhaps most intriguingly, I argue that universalism may cultivate public support in a way that transcends mere strategic "leveraging" of middle- and upper-income citizens' pursuit of their own egoistic interests. Rather, I explore the possibility that the degree of universality of a social assistance program might itself influence public preferences for redistribution. Standard "median voter" accounts of mass political behavior, grounded in traditional rational choice theory, have little to say about the potential for policies to shape or alter citizen preferences. Institutionally-oriented theorists within political science, law, and comparative welfare studies, by contrast, believe that the design of social policies can have a significant influence on the formation of social preferences. Institutionally-oriented theories, however, tend to be imprecise about the psychological mechanisms by which this might occur.

In this Article, I undertake to refine existing accounts of how policies can shape political preferences about redistribution by drawing upon the growing body of research in psychology and economics suggesting that people have a mixture of self-regarding and other-regarding impulses, and that some forms of social organization are more likely than others to elicit pro-social behavior. One finding is that people may be generous, even at personal cost, when participating in a cooperative enterprise in which they are satisfied that others are re-

14 Id. at 85-92 (describing relative success of middle- and upper-income parents, as compared with parents of lower socioeconomic status, in securing special educational resources for their own children in U.S. public schools).

15 See Daniela Caruso, Bargaining and Distribution in Special Education, 14 Cornell J.L. \& Pub. Pol'y 171 (2005) (arguing that special education laws have increased resources for children with disabilities, but the superior bargaining sophistication of wealthier parents in negotiating special education plans for their children has produced distributional inequities); Ruth Colker, The Disability Integration Presumption: Thirty Years Later, 154 U. Pa. L. Rev. 789, 794-95, 802-03 (2006) (tracing the massive increase in provision of public education to children with disabilities, and the profound shift from educating them in disability-only schools to doing so in regular public schools following passage of special education laws beginning in the 1960's). 
ciprocally cooperating. Second, beliefs about desert, and hence redistribution, are influenced by context and by how an issue is presented. Third, people tend to be more generous toward others whom they perceive as belonging to their own group, and identification with a particular group can be made more or less salient depending on context.

I argue that programs offering more universal protection against economic insecurity, because all contribute and all might receive benefits, fit more readily with reciprocity ideals than a program that taxes some citizens and transfers benefits to others. If participants feel that others are contributing and cooperating, they might more readily tolerate redistribution within the scheme, even at personal cost. ${ }^{16}$ Conversely, means testing, by making poverty-based group status highly salient, might undermine public generosity. In targeted programs, some citizens must be singled out as needy. Public debate over who is in and who is outside the group that "deserves" benefits might only sharpen public focus on fraud and abuse at the eligibility margin, and reinforce the tendency among some people to make sense of the persistence of poverty by attributing blame to those who are needy. Under a more universal system, boundary questions disappear and thus poverty-based "out-group" perceptions-and with them, attributions of blame and opportunism that undermine trust in fellow citizens-become less salient. Aspects of identity that all citizens shareanxiety about common life-cycle risks-become more salient. Thus at minimum, a universalist "policy frame" might reduce barriers to public support of redistributive social policy. Beyond that, however, to the extent that a more universal beneficiary class perceives itself as being "in this together" and having a common vulnerability, it is possible that more universalist welfare institutions could facilitate a type of social learning that alters social preferences in a more stable way over time, evolving towards greater tolerance of redistribution.

Let me emphasize that I do not mean to advocate the use of "tricks" from behavioral psychology to mislead citizens into voting for progressive social policies when they think they are doing otherwise.

16 The concept of reciprocity has sometimes been used as a way to justify work requirements or other quid pro quo devices that require recipients of means-tested benefits to earn their entitlements. See, e.g., Amy L. Wax, Rethinking Welfare Rights: Reciprocity Norms, Reactive Attitudes, and the Political Economy of Welfare Reform, 63 Law \& Contemp. Probs. 257, 291 (2000) (suggesting that an unconditional guarantee of welfare rights would come into conflict with widely-held notions of reciprocity and fairness); see also Noah D. Zatz, What Welfare Requires from Work, 54 UCLA L. Rev. 373, 445-51 (2006) (analyzing the analytic foundations of such arguments). My argument takes a different tack by emphasizing the ways in which universally-allocated benefits can themselves satisfy reciprocity ideals and in doing so, increase tolerance of redistribution within universal programs. 
My normative ideal is to design institutions in a way that increases public tolerance for redistribution without obscuring its existence.

If my thesis is plausible, how might we think about law reform moving forward? Following exposition of my core analytic claims, I sketch out an illustrative case study of recent legislation in California that established a program of paid family leave insurance that offers wage replacement to workers who must take leaves of absence to care for infants or seriously ill family members. I do not present the illustration as a sample "success story." On the contrary, I believe (and we should predict) that it is too early to know. Instead, I use it as an opportunity to think about a research agenda that would help evaluate the strength of my thesis.

The Article proceeds as follows. Part II sets out some operating definitions to lay the groundwork for my argument. In Part III, I explore economic arguments in favor of universalist provisions. I explain how the standard economics of public finance may supply an efficiency rationale for universal social risk pooling grounded in correction of information-based market failures. If income redistribution is the goal, however, conventional economic theory would at least facially favor targeting. In Part IV, I turn to insights from political science to show that, efficiency aside, political considerations may favor universal provision for achieving redistribution. I argue, however, that existing theory on the politics of universalism and wealth redistribution has failed to offer a sufficiently particularized account for the motivational underpinnings of this phenomenon. In Part V, I introduce a parallel literature from psychology and behavioral economics that enriches our understanding of redistributive motivation. Bringing this literature to bear on the political account from Part IV, I contend, enables us to think in a more nuanced way about the political and institutional conditions under which the public might support redistributional social policy. Part VI illustrates this argument by discussing some specific institutional design dilemmas and explains why some choices might be better than others for achieving redistribution. Part VII is a case study testing my thesis. In Part VIII, I push my thesis further still by considering whether universal welfare benefits might change attitudes on more than merely a transitory basis, inculcating what is variously referred to as "social solidarity," fellow-feeling, or a sense of collective responsibility. Part IX concludes.

\section{Defining Terms}

Before I develop my substantive thesis, I must clarify some key terms. As used in this Article, the term "welfare state" broadly refers to government intervention in the economy to facilitate provision of 
cash benefits, health care, education, food, housing, and other goods associated with health and well-being. ${ }^{17}$ The goal of the welfare state is in part to enhance the welfare of the poor (including the working poor), largely through "vertical" redistributive transfers from well-off citizens to less well-off citizens, and in part to facilitate coordination, where private markets fail, of risk pools against common social risks and consumption smoothing across the life-cycle. ${ }^{18}$ It is also sometimes argued that a further objective of the welfare state is to enhance an aspect of community that might be referred to variously as social cohesion, social solidarity, or a sense of collective responsibility. ${ }^{19}$

Welfare states may use different mixes of private and public provision, direct and indirect regulation of behavior, cash and in kind benefits, and-of particular importance for this Article-universal and targeted allocations of benefits. ${ }^{20}$ Although the welfare state spans many different areas of social policy, for example, public education, housing, and environmental protection, my focus here is the various institutions that protect income security-"social insurance" in the broad sense. I make this my focus in part because it is a major aspect of the welfare state, and in part because I view it as a challenging case, in some respects, for the ultimate themes I explore about the possibilities for shaping preferences more tolerant of redistribution.

The very broad definition of social insurance offered by Michael Graetz and Jerry Mashaw is helpful for framing the central trade-off I evaluate. Graetz and Mashaw define social insurance as a collective

17 A helpful overview is provided in Nicholas Barr, The Economics of the Welfare State 6-13 (4th ed. 2004).

18 Id. at $10-11$.

19 The work of T.H. Marshall has been very influential in this regard. See T.H. Marshall, Citizenship and Social Class, in Citizenship and Social Class and Other Essays 1,56 (1950) (articulating a role for the welfare state in creating a "common experience" across classes). More recently, see, e.g., Nicholas Barr, Economic Theory and the Welfare State: A Survey and Interpretation, $30 \mathrm{~J}$. Econ. Lit. 741, 746-47 (1992) (listing social solidarity as one among several possible objectives of the welfare state); Neil Gilbert, Transformation of the Welfare State: The Silent Surrender of Public Responsibility 157-72 (2002) (reviewing arguments linking the welfare state with social solidarity).

20 Welfare state intervention can be implemented using a wide variety of actors and instruments. First the government can directly provide services, for example, education, cash social assistance (what we generally think of as "welfare"), job training, old-age pensions, unemployment insurance, health insurance, hospitals, and so on. Second, it can impose monetary taxes or subsidies on behaviors to increase or decrease the marginal cost of specified behaviors, for example, taxes on consumption of cigarettes, alcohol, and gasoline, and subsidies or tax credits for investments in low-income housing, health insurance, dependent care, mortgage interest, charitable donations, corporate health benefits, and retirement plans. Third, it can regulate behavior directly: prohibit sales of alcohol to minors, prohibit discrimination in housing and employment, or mandate that employers provide workers' compensation. Finally, the government may finance private provision, for example the subsidization of private entities that offer prescription drug insurance to disabled and elderly individuals. 
means for providing income security against a set of common risks that span the life cycle-youth, old age, illness, disability, death, involuntary unemployment, or illness or infirmity of one's dependents. ${ }^{21}$ They include within the scope of this broad definition three kinds of social provision: (1) means-tested, noncontributory programs, (2) mandatory contributory (usually wage-financed) programs with benefits calibrated to earnings-what people conventionally mean when they use the term "social insurance," and (3) voluntary employersponsored pension plans, health insurance, and other fringe benefits subsidized by government tax expenditures. ${ }^{22}$ In this Article, I generally use the term "social insurance" in the conventional sense-to mean something most closely resembling (2)-although the broader view is helpful for sorting through the spectrum of social provision designed to protect income security.

Means- or income-tested programs restrict eligibility to individuals whose personal or family income is below some threshold. The specific formula for defining the eligibility cut-off differs across programs. Examples of such programs include Temporary Assistance for Needy Families ${ }^{23}$ (TANF, the current manifestation of what was known, between 1935 and 1996, as Aid to Families with Dependent Children, or AFDC $^{24}$ ), the Earned Income Tax Credit, ${ }^{25}$ Supplemental Security Income (SSI) ${ }^{26}$ (directed at low-income elderly and disabled people), Medicaid, ${ }^{27}$ Food Stamps, ${ }^{28}$ Head Start, ${ }^{29}$ the National School Lunch Program,,$^{30}$ the Special Supplemental Nutritional Program for Women, Infants and Children, ${ }^{31}$ and the Housing Choice Voucher Program. ${ }^{32}$ These programs are funded by direct expenditures from general tax revenues, rather than earmarked contributions by beneficiaries. Many of these programs also condition eligibility on other factors as well - for example, the presence of children in the family or earned income.

21 Graetz \& Mashaw, note 5, at 56. More precisely, they define social insurance as "collectively determined and legally binding promises to pay defined amounts to or on behalf of particular beneficiaries given the occurrence or continuation of an event or condition that impairs the adequacy of current family income." Id. at 57.

22 Id. at 61-62.

2342 U.S.C. $\$ \$ 601-619$ (2006 \& Supp. 2009).

24 See 42 U.S.C. $\$ \S 601-617$ (1994) (repealed 1996).

25 IRC $\$ 32$.

2642 U.S.C. $\$ \$ 1381-1383 f$ (2006 \& Supp. 2009).

2742 U.S.C. $\$ \S 1396-1396 w-2$ (2006 \& Supp. 2009).

287 U.S.C. $\$ \S 2011-2036$ (2006 \& Supp. 2009).

2942 U.S.C. $\$ \$ 9831-9852 c$ (2006 \& Supp. 2009).

3042 U.S.C. $\$ \S 1751-1769 i$ (2006 \& Supp 2009).

3142 U.S.C. $\$ \S 1786$ (2006 \& Supp. 2009).

3242 U.S.C. $\$ 1437 f$ (2006 \& Supp. 2009). 
The key feature of programs conventionally understood to be universal is that eligibility for benefits is not conditioned on income. Eligibility is typically based on a prior record of contributions, and triggered by some specific contingency, such as unemployment, disability, or retirement after reaching a particular age. The major federal and state social insurance programs, such as Social Security (a federal program funded by payroll taxes that provides retirement income, survivors' benefits, and disability coverage for eligible workers and their dependents) ${ }^{33}$ and Medicare (a federal program funded by payroll taxes and general revenues that provides hospital and medical benefits for persons age 65 and older and people with certain disabilities), ${ }^{34}$ fall in this category.

Having defined these ideal types, let me now clarify that the qualitative comparison of "targeting" to "universalism" risks overstating the distinction between them. It would be possible, for example, to characterize means-tested programs as a form of "universal insurance against experiencing severe poverty" (and moreover we might underestimate the number of citizens or households that at some point will fall below the means threshold for traditional welfare benefits). ${ }^{35}$

So, too might we overstate the universality of "universal" provision. Most programs we ordinarily think of as universal involve some degree of conditionality, for example, a minimal work history for Social Security benefits. Furthermore, some "universal" programs tend to be functionally (though not expressly) targeted at middle- and highincome individuals. For example, a substantial portion of government social spending takes the form of tax expenditures mainly benefiting higher earners. ${ }^{36}$ The beneficiaries of voluntary employer-based health and welfare programs subsidized by tax expenditures (Cate-

\footnotetext{
3342 U.S.C. $\S \S 401-434$ (2006 \& Supp. 2009).

3442 U.S.C. $\$ 1395$ (2006 \& Supp. 2009).

35 This characterization would be akin to the stylized original position in Rawlsian political thought, where no one knows his place or likely place in society; thus all programs redistributing resources from the well-off to the less well-off could be considered insurance against the hypothetical fate of ill-fortune. See John Rawls, A Theory of Justice 17-19 (2d ed. 1999).

36 See Christopher Howard, The Hidden Side of the American Welfare State, 108 Pol. Sci. Q. 403, 413-16 (1993) (concluding that "the middle- and upper-income classes are the main beneficiaries of the hidden welfare state," citing data showing that federal budget outlays on tax expenditures in 1990 were roughly one-third of what the government spent on traditional social insurance and means-tested social programs, and that the tax expenditures subsidizing corporate pensions and health insurance were among the largest in the U.S. welfare state). For more recent data, reaching similar results, see Leonard E. Burman, Christopher Geissler \& Eric J. Toder, How Big Are Total Individual Income Tax Expenditures, and Who Benefits from Them?, 98 Am. Econ. Rev. (Papers \& Proc.) 79, 82, tbl.3 (2008) (data showing that tax expenditures in the individual income tax "benefit highincome taxpayers more than low-income taxpayers in absolute terms and relative to their income, but less relative to the taxes they pay").
} 
gory (3) in Graetz \& Mashaw's definition of social insurance ${ }^{37}$ ) are disproportionately salaried, high-earning employees with stable, fulltime jobs. ${ }^{38}$

While the distinction between means-tested and universal programs is (like other categorical labels) susceptible to analytic deconstruction, I would defend the distinction on a number of grounds. First, a narrower, and (by definition) more economically distinct group of citizens actually receives transfers from means-tested programs than from programs popularly understood as universal such as Social Security and Medicare. And there are programs that occupy points in between. Thus it is probably most accurate to speak of degrees of universality, but there are degrees. Second, although we may all, as an analytic matter, be "insured" against severe poverty, my sense is that as a cognitive matter, middle- and upper-income Americans fail to perceive themselves as direct beneficiaries of means-tested welfare programs because they consider it unlikely that they will fall into severe poverty. For practical purposes, even as they enjoy the benefits of certain forms of government social spending, better-off citizens will tend to think of means-tested welfare programs as targeted at people other than themselves-at people who are currently poor and are overwhelmingly likely to remain poor. This cognitive distinction between, say, retirement or medical emergencies (events perceived to happen to most people) and severe poverty (something that happens to "poor people," or "disadvantaged people") is, I argue, significant in itself.

I wish to emphasize two final points before moving on. I argue that more universalistic social insurance programs may increase progressive redistribution, but of course the devil is in the details. The stringency of eligibility criteria can vary widely, thus influencing the functional inclusivity of a given program, especially with respect to those whose attachment to the labor force is more precarious. This, in turn, will affect the degree to which a given "universal" program is capable of progressive income redistribution. ${ }^{39}$ For reasons I will elaborate more fully below, expanding universality might require efforts to cover the lowest wage-earners while not severing entirely the

37 See text accompanying note 22 .

38 See Gillian Lester, Careers and Contingency, 51 Stan. L. Rev. 73, 100-01 (1998) (describing the common exclusion of workers from employment-based fringe benefits such as pensions and health plans on the basis of insufficient past earnings or hours or lack of sufficient work history with one employer).

39 See, e.g., Gillian Lester, Unemployment Insurance and Wealth Redistribution, 49 UCLA L. Rev. 335, 337-38, 348, 389 (2001) (discussing the stringency of eligibility criteria for unemployment insurance and its functional effect of excluding many low-wage workers). 
wage-earning link that can help avoid problems of moral hazard that might otherwise undermine the public legitimacy of the cooperative enterprise of social insurance.

It also bears emphasis that I do not argue for the elimination of means-tested programs. Some hazards that are hard to define-incapacities that fall short of disability but impede wage earning, the ill fortune that may undermine opportunity or erode community or family support systems-may interfere with one's wage-earning capacity in ways that are difficult or impossible to overcome. ${ }^{40}$ If expanding universal programs is successful in facilitating income redistribution to low-income citizens, we would expect the size of the population that experiences severe poverty to decline, but that does not mean it will disappear. There remains an important role for protection of those who incur risks or hardships that are beyond the grasp of even more encompassing universal programs.

\section{Economic and Political Arguments in Favor of Universal Social InSURANCE}

Both economists and political scientists have offered arguments favoring universal provision of social insurance. In this Part I review these arguments in turn. An understanding of existing arguments from both disciplines helps to situate my subsequent arguments as to the ways in which standard accounts are incomplete, or at least not specific enough, in explaining the formation of social preferences.

\section{A. The Efficiency Case for Social Insurance: Overcoming} Market Failures

Mainstream public finance theory views social insurance as predominantly a mechanism for correcting or surmounting information and collective action problems that impede private risk pooling. ${ }^{41}$ Redistribution between rich and poor, if it occurs at all, is treated as largely epiphenomenal. Rather, if vertical redistribution (from rich to poor) is normatively desirable, it is best accomplished through the use of targeted transfers conditioned on means. ${ }^{42}$

Social insurance can be seen as a large-scale version of mutual insurance, a mechanism for protection against uncertain future losses

40 Graetz \& Mashaw, note 5, at 64 (describing varieties of difficult-to-categorize hazards to income adequacy).

41 Barr, note 17 , at 116-17.

42 Barr, note 19 , at 746,755 (identifying vertical equity as a possible objective of the welfare state and distinguishing between "social insurance," which does not in its pure form seek vertical redistribution, and "social assistance," which does). 
that operates by pooling the resources of individuals who face uncertainty. Pooling makes it possible to estimate the probability of loss in situations where it may be impossible to determine whether a given individual will incur a loss. To the extent people tend to be risk averse, insurance increases social welfare by reducing the psychological burden of uncertainty.

Certain risks, such as illness or unemployment, or loss of wageearning capacity in old age, are common to many people over their life cycle. Given the potentially unexpected nature of illness and unemployment, an individual (or family) may be unable to accumulate an adequate savings buffer (and unable to obtain a loan) to absorb the losses. Insurance in these instances would increase social welfare by helping both to buffer against income interruptions with unexpected timing, and to smooth consumption over the life cycle..$^{43}$

Competitive insurance markets typically rely on a number of conditions, many of which depend on the availability of accurate information. ${ }^{44}$ For example, an insurer needs to be able to quantify risk in order to set an actuarially fair (and therefore efficient) price. The problem is that certain kinds of social risk factors-such as macroeconomic shifts that affect unemployment, or technological changes that affect the costs of health care-can be very difficult to quantify.

Private insurers also need accurate information about the personal risk characteristics of potential claimants, for example, how healthy they are. If there are significant information asymmetries between insurers and consumers, private insurance may be impossible. ${ }^{45}$ Suppose, for example, that prospective insurance buyers have systematically better information about their own health risks, unob-

${ }^{43}$ See, e.g., Zvi Bodie, Pensions as Retirement Income Insurance, 28 J. Econ. Lit. 28 (1990) (describing the insurance function of pension plans).

44 Private market insurance sets the price an individual must pay to participate (the premium) according to the probability they will incur a loss. Stated formally (and very simply), the competitive (or "actuarial") insurance premium is $\pi_{i}=p_{i} L+T$, where $p_{i}$ is the probability of the insured event occurring, $L$ is the magnitude of the insured loss, and $T$ is transaction costs. If accurate information about the factors in the equation cannot be obtained, then it may be impossible to set an efficient price. See generally Steven Shavell, Economic Analysis of Accident Law 197-98 (1987) (reviewing information problems that interfere with efficient insurance); J. Hirshleifer \& John G. Riley, The Analytics of Uncertainty and Information-An Expository Survey, 17 J. Econ. Lit. 1375, 1389-91 (1979) (providing a graphical example of the informational problem faced by insurers); Michael Rothschild \& Joseph Stiglitz, Equilibrium in Competitive Insurance Markets: An Essay on the Economics of Imperfect Information, 90 Q.J. Econ. 629, 633-37 (1976) (graphically demonstrating an insurance market based on imperfect information).

${ }^{45}$ See generally Mark V. Pauly, Overinsurance and Public Provision of Insurance: The Roles of Moral Hazard and Adverse Selection, 88 Q.J. Econ. 44 (1974) (asserting that private insurance markets are nonoptimal compared to public provision due to information asymmetry). 
servable to insurers. This can give rise to a problem of adverse selection. Without means to distinguish between "high-risk" and "lowrisk" consumers, a private insurance provider could charge a premium that is actuarially competitive on average, effectively presuming the presence of both high- and low-risk consumers. But such practice would probably be a poor business strategy because low-risk consumers might balk at that average premium (which implicitly subsidizes high-risk consumers) and exit the market. If all such individuals were to exit, the private market provider would realize (at least eventually) that all its clients were high-risk and raise its premium. The ultimate outcome (sometimes referred to as "the market for lemons") ${ }^{46}$ is that a private market will supply insurance only to the high-risk individuals (at an actuarially fair rate for that group), with others-who would like to be insured, but only at a fair price-inefficiently failing to purchase insurance.

Another information-based problem that affects insurance markets concerns private information about actions (that is, moral hazard), whereby an individual who is fully insured will reduce efforts to avoid injury (ex ante moral hazard) or to mitigate costs, for example, consumption of health care services, after occurrence of a covered harm (ex post moral hazard). ${ }^{47}$ The insurer's inability to monitor behavior perfectly means that it is unable to adjust prices to account for the level of precaution. Consequently, it will charge rates that reflect an expectation that consumers will (inefficiently) reduce efforts to avoid loss. ${ }^{48}$

Compulsory social insurance can provide the benefits of risk pooling to all who potentially value it more cheaply than private providers because it obviates the necessity of sorting individuals based on unobservable or only partially observable characteristics and improves the ability of the insurer to adjust ex post the cost of insurance if there are unexpected changes in risk of hazard or cost of losses. ${ }^{49}$ Compulsory provision can also address bargaining failures that may impede effi-

46 See George A. Akerlof, The Market for "Lemons": Quality Uncertainty and the Market Mechanism, 84 Q.J. Econ. 488, 489-90 (1970) (classic demonstration that where the quality of used cars cannot be ascertained, sellers with higher quality cars, because they cannot be fully rewarded, will exit the market leaving behind a "market for lemons").

47 See generally Pauly, note 45, at 54-56. There may also be moral hazard by intermediaries who provide services, for example, a doctor who prescribes more services than are necessary knowing that the cost of her services will be indemnified by insurance.

48 Steven Shavell, On Moral Hazard and Insurance, 93 Q.J. Econ. 541 (1979) (modeling the optimal insurance policy, where the cost of insurance factors in the ability of the insurer to observe the level of care by the insured).

49 Similar arguments can be made for the efficiency of compulsory intergenerational transfers (for example, public pensions) financed either through accumulation of reserves, or pay-as-you-go financing, whereby current workers finance the pensions of current retirees. Here, state intervention enables efficient life-cycle income smoothing as a buffer 
cient provision such as myopia, signaling problems, collective action failures on the part of workers, and the like. ${ }^{50}$ The costs imposed by moral hazard are more organic to the provision of insurance generally, and government provision may offer a comparative advantage. Parallel to private insurance, social insurance contains devices designed to reduce moral hazard, such as copayments, deductibles, and so forth, but in addition the state may in some spheres be able to monitor and control behavior directly, backed by civil and criminal laws and attendant investigative and enforcement powers..$^{51}$

According to standard public finance theory, the major efficiency risk of public mandates is crowd-out. ${ }^{52}$ Where a private market for goods or services already exists, introduction of universal government provision at no or reduced cost to public consumers might crowd out consumption of private goods and lead to a net depletion in supply. Of course, the private income freed up may be spent on things that are socially beneficial, and therefore it is possible that universal provision would increase social welfare. However, it is also possible that wealth or labor substitution effects will occur that reduce social welfare: Some of those whose wealth increases may substitute leisure for

against various risks by virtue of its capacity for a larger mutualization both between and within age cohorts.

${ }^{50}$ For general reviews of the extensive literature on bargaining failures in labor markets, see Richard Edwards, Rights at Work: Employment Relations in the Post-Union Era 42-76 (1993); Paul C. Weiler, Governing the Workplace: The Future of Labor and Employment Law 74-78 (1990); Christine Jolls, Cass R. Sunstein \& Richard Thaler, A Behavioral Approach to Law and Economics, 50 Stan. L. Rev. 1471, 1476-79 (1998); see also Deborah Weiss, Paternalistic Pension Policy: Psychological Evidence and Economic Theory, 58 U. Chi. L. Rev. 1275, 1297-311 (1991) (discussing savings failures caused by myopia, time-inconsistent preferences, and impulsiveness); David Laibson, Golden Eggs and Hyperbolic Discounting, 112 Q.J. Econ. 443 (1997); Joseph Bankman, Tax Policy and Retirement Income: Are Pension Plan Antidiscrimination Provisions Desirable?, 55 U. Chi. L. Rev. 790, 808-09 (1988) (suggesting that rank-and-file employees may place less value on pension benefits, at the expense of salary, than more highly compensated employees).

51 David A. Moss, When All Else Fails: Government as the Ultimate Risk Manager 5051 (2002). Of course, government provision of insurance may introduce problems of its own relative to market provision. "Government failure" may arise because neither the public not elected officials have full information about the actions of agencies and officials; bureaucrats may be vulnerable to capture by powerful actors or interest groups having a stake in the design of redistributional policy; agencies and officials may commit errors given imperfect information about the costs and benefits of various policy choices; or government may become inefficiently large and consequently suffer inertia and inflexibility. Some also hold the view that freedom is compromised by the paternalism inherent in government-imposed risk pooling, or that citizens will come to over-rely on government for social welfare at the expense of self-reliance. See generally Barr, note 17, at 755-57; Ayre Hillman, Public Finance and Public Policy: Responsibilities and Limitations of Government 775-78 (2d ed. 2009); Matthew D. McCubbins, Roger G. Noll \& Barry W. Weingast, Slack, Public Interest, and Structure-Induced Policy, 6 J.L. Econ. \& Org. 203, 208 (1990).

52 Harvey S. Rosen \& Ted Gayer, Public Finance 218-22 (8th ed. 2008) (giving theory and illustrations). 
labor and thus reduce productivity. Simultaneously, assuming the need to balance the budget, more universal provision will require an increase in marginal tax rates and those who bear the increase may have reduced incentive to work. If social consumption of a good is low or nonexistent before government provision, crowd-out of private market provision is not likely to be significant. Instead, government intervention might crowd out "self-insurance," that is, private savings, or reliance on church, family, and friends for social support. ${ }^{53}$

A key point here is that conventional efficiency-based justifications for compulsory universal social insurance tend to focus on correcting market failure rather than on redistribution. True, those who make claims on the pool receive transfers that those who do not make claims do not. But from an ex ante perspective, people do not know whether they will suffer a loss; the decision to join the pool is based on a rational prediction that the utility from reducing uncertainty equals or exceeds the cost of membership. It is also true that by mandating participation by individuals who would exit from a private insurance market, public insurance effectively redistributes resources from lowrisk to high-risk populations relative to the market. Public pensions, for example, tend to redistribute resources from young to older generations (assuming pay-as-you-go financing), and from people with short to long life spans. These forms of horizontal and temporal redistribution may or may not reduce poverty or income inequality, depending on whether higher-risk people tend also to have low incomes. To the extent one has the normative goal of vertical redistribution (from rich to poor), means testing is conventionally viewed as more direct and efficient.

\section{B. Target Efficiency}

Where redistribution is one's goal, orthodox economic theory would suggest that means-tested transfer of goods, services, or cash is the most efficient method. Means-based targeting, however, has its own inefficiencies, with economists disagreeing on whether they tip the balance of net efficiency. ${ }^{54}$

53 Note that crowd-out is not necessarily undesirable. The state might decide to create public programs with the goal of inducing "crowd-out" of private insurance in instances where private provision results in either significant market failure (see above) or significant distributional inequities. If, however, government provides a good at a quality that is lower or price that is higher than an individual could have obtained by purchasing it privately, there may be a loss of welfare.

54 See generally, Ravi Kanbur \& Nick Stern, Transfers, Targeting and Poverty, 2 Econ. Pol'y 111, 124-25 (1987) (reviewing empirical studies that try to evaluate this question); Nicholas Rowe \& Frances Wooley, The Efficiency Case for Universality, 32 Can. J. Econ. 613 (1999) (arguing that universal provision is more efficient in alleviating poverty than 
For example, efforts to target social transfers toward only low-income citizens are bedeviled by a number of administrative costs. Setting aside questions (having both administrative and normative dimensions) as to where to draw the eligibility line, how to measure need, what social unit (for example, individual versus family) ought to be used for measuring one's resources, and the relevant time period over which to measure resources and needs, implementation of a targeted scheme faces certain administrative costs that accompany the use of an income "cut-off." For example, there can be problems of both over- and under-inclusiveness. Those who fall above the benefits cut-off may have incentives to conceal information in order to claim eligibility, giving rise to administrative costs associated with monitoring "leakage" outside the class of intended beneficiaries. On the flip side, there may be problems of incomplete take-up of benefits by intended beneficiaries due to lack of awareness of benefits, administrative difficulties associated with verifying eligibility, and avoidance of the perceived stigma of collecting benefits. 55

Beyond administrative costs, however, perhaps the central efficiency-based case against means-tested transfers as a method for reducing poverty is its potential effect on labor supply. Means testing functionally imposes a marginal tax rate (the proportion of the last dollar of income taxed by the government) of $100 \%$ on all whose resources fall short of the transfer threshold. ${ }^{56}$ The resulting disincentive for program beneficiaries to increase their earnings can lead to a "poverty trap": To the extent work effort falls, incomes fall, and even more resources will be required to fill the gap between existing resources and minimal sufficiency. This will mean an even higher tax on those above the poverty line-which will, in turn, adversely affect work incentives. The government can try to reduce the implicit marginal tax rate on the poor, but assuming the need to balance the budget, this requires either reducing the size of the pool that receives transfers, or increasing the tax imposed on the public to pay for the benefit. The trade-offs here are either fewer people whose poverty is reduced (due to the lower transfer threshold) or, again, reduced work effort by those who must pay higher taxes to offset the reduced marginal tax

means testing); Timothy Besley, Means Testing Versus Universal Provision in Poverty Alleviation Programs, 57 Economica 119 (1989) (arguing the opposite).

55 See generally, A.B. Atkinson, Incomes and the Welfare State: Essays on Britain and Europe 247-55 (1995); Janet Currie, The Take-Up of Social Benefits, in Public Policy and the Income Distribution 80-148 (Alan J. Auerbach, David Card \& John M. Quigley eds., 2006) (arguing that administrative barriers are more significant than stigma in explaining incomplete take-up of means-tested benefits).

56 Anthony B. Atkinson, On Targeting Social Security: Theory and Western Experience with Family Benefits, in Public Spending and the Poor 25, 59-63 (Dominique Van de Walle \& Kimberly Nead eds., 2001). 
rate for the poor. This example is deliberately simple, but sufficient to illustrate the general point that means-tested redistribution schemes are susceptible to certain endogenous costs associated with the establishment and maintenance of a benefits cut-off based on income.

In sum, compulsory social insurance may be efficient but need not be especially redistributive, and means-tested provision may be redistributive in theory, but not especially efficient in practice. Social insurance is capable of vertical redistribution, but whether it achieves a measure of both efficiency and redistribution depends crucially on the particularities of institutional design. Analyzed purely as a matter of economic theory, there may in some cases be a tension between efficiency and redistribution. The economics of social welfare provision, however, is not the only relevant mode of analysis. The study of politics brings to bear a distinct set of considerations. As Part IV elaborates, political analysis of social welfare institutions may argue in favor of universal provision for achieving redistribution.

\section{Political Arguments for Universal Provision}

Political theories of why greater redistribution might occur within more universal regimes fall within several categories. One tradition hypothesizes that the variety of forms of welfare states reflects cultural differences between nation-states, for example, between the more "egalitarian" western European democracies and more "individualistic" democracies such as the United States. The argument is that more egalitarian cultures will choose welfare states that are more encompassing and more redistributional. The absence of a feudal past in the United States, putative commitment to social mobility, and relative lack of class-consciousness have been offered to explain its parsimonious welfare state..$^{57}$ In a conceptually similar vein, some explanations turn on cross-national differences in racial and ethnic makeup. The relative (at least historically) racial and ethnic homogeneity of western European states has been hypothesized to exert an important influence on welfare state generosity when compared to the

57 See, e.g., Seymour Martin Lipset, The First New Nation: The United States in Historical and Comparative Perspective (1963); Seymour Martin Lipset, American Exceptionalism: A Double-Edged Sword (1996); Erzo F.P. Luttmer \& Monica Singhal, Culture, Context, and the Taste for Redistribution, 3 Am. J. Econ. Pol'y 157 (2011). The "American exceptionalism" thesis is the subject of considerable debate. See, e.g., William F. Forbath, The Shaping of the American Labor Movement, 102 Harv. L. Rev. 1109, 1118-25 (1988) (conducting an historical analysis to argue that the standard account of the nineteenth century U.S. labor movement overlooks elements of class-consciousness and radicalism that ultimately bowed to the triumph of voluntarism in the face of a constraining legal order). 
United States whose legacy of slavery and progressive waves of immigration have produced a more racially and ethnically divided society. ${ }^{58}$

Another approach applies median voter models in the rational choice tradition. Median voter models begin with the assumption that voter preferences and incentives are aligned around rational self-interest. On this assumption, these models predict that-under various conditions-policy choices will tend to be "middle of the road" or moderate, and ignore strong preferences of voters on one side of the spectrum or the other. ${ }^{59}$ Where most voters fall within a particular demographic group or class stratum, policy choices will be dominated by the middle-of-the road view within that class. ${ }^{60}$ This reasoning has led to the hypothesis, for example, that the "poorer" the median voter relative to the mean income available for redistribution, the stronger the median voter's support for higher taxes and social spending. ${ }^{61}$ If the median voter is in the middle of the income distribution, programs that benefit middle-income voters are both more likely to be created and more likely to survive than means-tested programs that tax but do not benefit the middle. One implication of this is the so-called "paradox of redistribution": Although means- testing would appear to be a

58 Alberto Alesina \& Edward L. Glaesar, Fighting Poverty in the U.S. and Europe: A World of Difference (2004); Gary M. Klass, Explaining America and the Welfare State: An Alternative Theory, 15 Brit. J. Pol. Sci. 427, 449-50 (1985); Jill Quadagno, The Color of Welfare: How Racism Undermined the War on Poverty 7 (1994).

59 See generally Roger D. Congleton, The Median Voter Model, in Encyclopedia of Public Choice (Charles K. Rowley \& Friedrich Schneider eds., 2004).

${ }^{60} \mathrm{I}$ am setting aside, for simplicity's sake, a number of alternative assumptions, such as "double-peaked" preferences, multiple- rather than single-issue elections, and the fact that collective decisionmaking is often mediated by institutions of representative democracy rather than direct democracy, that can make the model less useful in predicting outcomes. See id. at 385-86 (noting some theoretical limitations of the median voter model). Moreover, some scholars debate the predictive power of the median voter model as compared with other rational choice models of preference formation, such as interest-group models. See, e.g., Sultan Ahmed \& Kenneth V. Greene, Is the Median Voter a Clear-Cut Winner?: Comparing the Median Voter Theory and Competing Theories in Explaining Local Government Spending, 105 Pub. Choice 207 (2000); James R. Baumgardner, Tests of Median Voter and Political Support Maximization Models: The Case of Federal/State Welfare Programs, 21 Pub. Fin. Rev. 48 (1993).

61 Allan H. Meltzer \& Scott F. Richard, A Rational Theory of the Size of Government, $89 \mathrm{~J}$. Pol. Econ. 914 (1981) (arguing that the higher the ratio of the mean to the median voter's income, the stronger the median voter's support for higher taxes and social spending). Efforts to verify this thesis empirically have produced mixed results. See, e.g., Branko Milanovic, The Median Voter Hypothesis, Income Inequality and Income Redistribution: An Empirical Test with the Required Data, 16 Eur. J. Pol. Econ. 367 (2000) (finding a strong correlation between income inequality and wealth redistribution, but questioning whether the median-voter model explains this phenomenon given doubts as to whether middle-income groups are net beneficiaries of redistribution); Robert Moffitt, David Ribar \& Mark Wilheim, The Decline of Welfare Benefits in the U.S.: The Role of Wage Inequality, 68 J. Pub. Econ. 421 (1998) (finding a negative, rather than positive, correlation between income inequality and welfare spending and exploring explanations within median-voter paradigm). 
more direct and efficient way to redistribute income, the poor may be better off with universal provision. ${ }^{62}$

Middle-class ${ }^{63}$ voters might, of course, exert their considerable influence on the administration of universal programs to favor the welloff at the expense of the less well-off. ${ }^{64}$ This might be true, for example, where there is room for regional variation in the quality of services. Even assuming rent-seeking by well-off beneficiaries, however, redistribution might occur through universal welfare provision in several ways. Some universal benefits will have public goods-like features-public childcare, hospitals, schools, and the like-such that poor as well as nonpoor citizens will collectively benefit. Nonpoor citizens, acting in their own interests and having more social capital than the poor, have an incentive to ensure the programs are high quality. ${ }^{65}$ Alternatively, it may be practically impossible to prevent "spillover" of benefits to the extent that local actors who administer programs may exercise their discretion in a way that spreads resources more broadly. ${ }^{66}$

In weighing concerns about middle-class capture of universal benefits, it is always important to ask the question: "Compared to what?" The counterfactual can be very difficult to evaluate, especially given relatively limited state-to-state variations in practice in a number of areas of social provision, and the limitations of comparability between nation-states. ${ }^{67}$ If the only real choice is between a program that extends benefits to the middle class as well as poor and no program at all, the former may be preferable from the perspective of distributive justice. A more realistic comparison in the American context is to an

62 Korpi \& Palme, note 10, at 678 (finding negative correlation between degree of welfare state targeting and size of redistributive budget in eleven OECD countries); Walter Korpi, Approaches to the Study of Poverty in the United States: Critical Notes from a European Perspective, in Poverty and Public Policy 287-314 (V.T. Covello ed., 1980); Karl Ove Moene \& Michael Wallerstein, Targeting and Political Support for Welfare Spending, 2 Econ. Gov. 3 (2001) (modeling proposition that with self-interested voting, narrow targeting may so reduce the probability of receiving benefits for the majority that the majority prefers to eliminate benefits altogether).

63 The studies I describe typically use the term "middle class" without defining it. See note 11 (discussing "middle class" definitional issues).

64 See, e.g., Robert Goodin \& Julien LeGrand, Not Only the Poor: The Middle Classes and the Welfare State 210-11 (1987) (arguing that if the middle class is included as beneficiaries of welfare programs they will use their influence to expand services that benefit themselves and contract services for the poor); Kelman \& Lester, note 13.

65 Albert Weale, Equality, Social Solidarity, and the Welfare State, 100 Ethics 473, 484 (1990).

66 Kelman \& Lester, note 13, at 97-102 (describing the spill-over, sometimes deliberate, of the services of special education teachers in mainstreamed classrooms).

67 As noted earlier, empirical efforts to quantify the relative efficiency of poverty reduction of means-tested versus universal social welfare benefits within countries have produced mixed findings. See note 62 . 
existing status quo in which middle- and high-income citizens receive benefits through a system of quasi-private ordering subsidized by tax expenditures that in turn are financed by general revenues, while lowincome citizens depend on means-tested benefits that are ungenerous, short-term, and administratively burdensome to qualify for. Given this, more universal provision might increase redistribution by "beneficially" crowding out a system of private social provision that produces even more income inequality. ${ }^{6}$

A third major theoretical tradition views differences through a structural or "institutional" lens. Perhaps most famous is Gøsta Esping-Andersen's three-part typology of welfare regimes. ${ }^{69}$ The origins of different welfare states, in this view, evolved from both struggles and coalitions between social classes with competing interests. ${ }^{70}$ Different kinds of alliances between the working class and farmers, the working and middle classes, and the middle and upper classes led to different welfare state trajectories in different nations, including with respect to degrees of universalism and redistribution. ${ }^{71}$ A key tenet of the institutional view is that once in place, these different institutional structures had a profound impact on the future trajectory of a welfare state, with more universal schemes tending to cultivate different "fabrics" of social structure. ${ }^{72}$

Although a large literature is devoted to refining Esping-Andersen's typology, it remains widely influential. ${ }^{73}$ Even within more nuanced accounts, certain regimes tend to cluster along different points on the spectrum of level and kind of state involvement in welfare provision, with the United States (along with Canada, Australia,

68 Korpi \& Palme, note 10, at 681 (finding more redistribution in regimes where highincome earners receive earnings-related rather than flat-rate benefits, and speculating that it results from the combination of the appeal for the middle class of earnings-linked benefits and the subsequent crowd-out of even less redistributional private market insurance).

69 Gøsta Esping-Andersen, The Three Worlds of Welfare Capitalism (1990). This account built on earlier efforts to categorize welfare state types. E.g., Harold Wilensky \& Charles N. Lebeaux, Industrial Society and Social Welfare (1958).

70 A classic articulation of the "power resource" model is Walter Korpi, The Democratic Class Struggle (1983).

71 Id; see also Peter Baldwin, The Politics of Social Solidarity: Class Bases of the European Welfare State 1875-1975, at 29-30 (1990) (arguing interest group politics explains the rise of social insurance programs in Europe, where socialists saw an opportunity to buy political support by including the middle class and the middle class recognized the personal advantages of security against risk).

72 Esping-Andersen, note 69, at 23-26, 58.

73 See Clem Brooks \& Jeff Manza, Why Welfare States Persist: The Importance of Public Opinion in Democracies 21 (2007) (noting the continuing influence of the Esping-Andersen ideal regime-type theory despite vigorous academic debate). An example of an effort at revision, building upon but refining Esping-Andersen's typology, is Wil Arts \& John Gelissen, Three Worlds of Welfare Capitalism or More? A State-of-the-Art Report, 12 J. Eur. Soc. Pol'y 137 (2002). 
Ireland, and the United Kingdom) tending towards a "liberal" ideal type. ${ }^{74}$ This ideal type is characterized by state encouragement of private social provision, with government provision as a residual strategy, taking the form of means-tested assistance having strict eligibility requirements and modest benefits, modest universal transfers, and modest social insurance plans. ${ }^{75}$ The liberal regime-type is contrasted with the broadly universalistic "social-democratic" regime-type dominated by the Nordic countries and the hybrid "conservative" or "corporatist" regime of countries such as Austria, France, Germany, and Italy. ${ }^{76}$ Efforts to measure the redistributive effects at the national level of different ideal regime-types using both longitudinal and cross-national comparisons have found support for the hypothesis that social-democratic regimes are the most effective in reducing both poverty (raising the "floor") and inequality (reducing the difference between the top and bottom) along a range of conventional measures. ${ }^{77}$

Another institutional line of analysis focuses on "lock-in" following initial adoption of particular institutional arrangements. Policies may

74 Esping-Andersen, note 69, at 26-27; see also Brooks \& Manza, note 73, at 20-21 (also including New Zealand, Ireland and the United Kingdom in this group). This is sometimes also referred to as the "residual" regime type.

75 Four-fifths of the money the U.S. government spends on social protection goes to non-means-tested social insurance schemes, but when compared with most countries, the United States relies much more heavily on means-tested benefits. Lyle A. Scruggs \& James P. Allan, Social Stratification and Welfare Regimes for the Twenty-First Century: Revisiting the Three Worlds of Welfare Capitalism, 60 World Pol. 642, 652 tbl.3 (2008) (finding that in 2004 the United States ranked third, behind only Australia and New Zealand, of eighteen OECD countries in percentage of total social spending on means-tested programs).

76 In the Esping-Andersen typology, the social-democratic ideal type is characterized by universal social insurance schemes covering a wide swath of both cash and in-kind social provision, including many services (such as child and elder care) traditionally provided by the family, benefits graduated according to accustomed earnings, and a purported goal of "decommodification," or crowding out market provision. The corporatism regime combines state provision of social insurance and occupational fringe benefits with a commitment to the preservation of the traditional family, thus subsidizing women's traditional roles in the home and significantly limiting state provision of childcare and other services traditionally performed by the family. Esping-Andersen, note 69 , at 27-28. The categories are, however, not exclusive. For example, within the states generally categorized as "liberal" are some institutions that are quite universalistic, social democratic states that have not wholly avoided means-testing, and some states elude categorization into one type or another.

77 See, e.g., Goodin et al., note 75, at 152-86, 260 (finding consistent support for the regime-type hypothesis using a range of conventional measures of equality and poverty reduction); Korpi \& Palme, note 10, at $677-78$ (finding negative correlation between degree of welfare state targeting and size of redistributive budget in eleven OECD countries); see also Gøsta Esping-Andersen \& John Myles, Economic Inequality and the Welfare State, in Oxford Handbook of Economic Inequality (Wiemer Salverda, Brian Nolan \& Timothy M. Smeeding eds., 2009) (stressing the importance of breaking down "ideal-type" welfare regimes into more specified institutional characteristics such as taxation, direct income transfers, and services and calling for further development of this empirical agenda). 
encourage individuals to develop certain kinds of skills, make certain kinds of investments, and forge certain kinds of social networks that become "sunk" costs, thus making more difficult the adoption of other policies that might have been possible at an earlier juncture. ${ }^{78}$ This can occur at the level of political elites, who might resist deviation from existing institutions as a result of existing skills and bureaucratic infrastructure. ${ }^{79}$ It can also operate at the level of mass publics. Political scientist Paul Pierson gives the examples of post-World War II housing and transportation policies that encouraged particular spatial patterns of work, consumption, and residence, and Social Security's pay-as-you-go structure under which each generation becomes deeply invested in maintaining the existing system so as to avoid the possibility of double payment in the event of a switch to private provision. ${ }^{80}$

A variant on this view is the "policy-feedback" hypothesis that not only do interest groups create policy, but policies can create interest groups. The establishment of a new policy provides resources and incentives for mobilization of political actors and groups, who may come to define themselves in response to policies and act to reinforce them. ${ }^{81}$ Examples are studies tracing the mobilization of veterans as an interest group in response to civil war pensions, ${ }^{82}$ and the effect of Social Security on the formation of a group identity among older Americans as "senior citizens" and subsequent creation of lobby organizations such as the AARP (which in turn pressured political parties to maintain Social Security). ${ }^{83}$

Some scholarship in the policy-feedback vein has addressed the feedback effects of universal versus means-tested benefits. Political scientist Theda Skocpol has chronicled the failure of a number of targeted welfare programs in the United States, such as poorhouses, pensions for poor mothers, and the 1960's and 1970's "war on pov-

78 Paul Pierson, When Effect Becomes Cause: Policy Feedback and Political Change, 45 World Pol. 595, 608 (1993).

79 Id. at 603-05 (explaining how policies could influence political elites' development of administrative skills that in turn make it easier for them to maintain bureaucratic structures created by the initial policy).

80 Id. at 608-09; see also Jacob Hacker, The Divided Welfare State: The Battle over Public and Private Social Benefits in the United States (2002).

81 Pierson, note 78, at 599-601.

82 See, e.g., Theda Skocpol, Protecting Soldiers and Mothers: The Political Origins of Social Policy in the United States (1992) (arguing that Civil War pensions led to the selfconscious mobilization of veterans to demand improved benefits).

83 Andrea Louise Campbell, How Policies Make Citizens: Senior Political Activism and the American Welfare State (2003); cf. Benjamin I. Sachs, Employment Law as Labor Law, 29 Cardozo L. Rev. 2685 (2008) (arguing that employment laws that provide minimum standards or prohibit discrimination can incubate solidarity among workers protected by those laws and potentially stimulate labor mobilization more generally). 
erty" of the Kennedy, Johnson, and Nixon administrations. ${ }^{84}$ She contrasts these with other programs that have offered benefits across income groups, such as civil war benefits, health education services for mothers and babies, and Social Security. ${ }^{85}$ She argues that programs targeted at the poor have tended to be politically unpopular, received low levels of public investment, or suffered public backlash and been eliminated or scaled back over time, whereas programs with more universal benefits have had greater political success and survival. ${ }^{86}$ An important part of Skocpol's argument is that in each of the cases of universal benefits she studied, there was some progressivity or targeting of benefits within the universal scheme-what she calls "targeting within universalism"-and yet the programs maintained significant support from the mass public. ${ }^{87}$

Andrea Louise Campbell emphasizes the role of political participation in policy feedback, arguing that the effects of universal programs such as Social Security, Medicare, and the G.I. Bill on political participation tend to be positive, whereas they tend to be negative with targeted programs like welfare ${ }^{88}$ Citing the importance of individuals' material resources to their ability to participate in politics, Campbell argues that the generosity of universal programs like Social Security and Medicare as compared with targeted welfare programs significantly explains these effects. ${ }^{89}$ Furthermore, noting that major universal programs such as Social Security, Medicare, and the G.I. Bill have redistributed benefits towards the poor, ${ }^{90}$ she argues that they have disproportionately boosted the participation of low-income re-

84 See, e.g., Theda Skocpol, Social Policy in the United States: Future Possibilities in Historical Perspective 253-74 (1995).

85 Id.

86 Id. at 253.

87 Id.

88 Andrea Louise Campbell, Targeting, Universalism, and Participation, in Remaking America: Democracy and Public Policy in an Age of Inequality 121, 123 (Joe Soss, Jacob S. Hacker \& Suzanne Mettler eds., 2007) [hereinafter Remaking America].

${ }^{89}$ Id. at 129-30. Campbell also suggests that differences in the way state agents interact with clients tend to differ in systematic ways-with some exceptions-between universal social insurance schemes and means-tested programs so as to influence clients' sense of esteem and efficacy. Id. at 127-28. On this point, see, e.g., Joe Soss, Lessons of Welfare: Policy Design, Political Learning, and Political Action, 93 Am. Pol. Sci. Rev. 363 (1999) (arguing, in comparing AFDC, Head Start, and Social Security Disability Insurance recipients, that attitudes towards demand-making are shaped by the design of different welfare institutions and that this has a spill-over effect into their sense of efficacy in the political sphere more generally).

90 Campbell, note 88, at 129 (noting that low-income Social Security beneficiaries receive higher benefits as a proportion of their preretirement incomes than higher-income workers, low-income Medicare beneficiaries over a lifetime receive more benefits because on average they are sicker and less likely to have supplemental insurance, and the G.I. Bill made more of a difference to World War II veterans from modest backgrounds in providing educational opportunities than it did to more affluent veterans). I consider the com- 
cipients compared with other recipients, thus democratizing participation within client groups. ${ }^{91}$ At the same time, she argues, the sizeable benefits that universal programs confer on middle-class and affluent beneficiaries crucially undergird the programs' overall political support. ${ }^{92}$ In sum, Campbell argues, universal programs give both highand low-income beneficiaries "the means and the motive" to participate concerning the programs. ${ }^{93}$

To draw the strands of this part of my analysis together, one can give a number of plausible political explanations for why welfare states with a richer concentration of universal, as compared with means-tested, welfare programs might be more successful in achieving meaningful redistribution. Middle-class pressure for improvements to social programs from which they stand to benefit might "raise all boats," with those gains inevitably spilling over to the benefit of others; broader inclusion might increase the resources and incentives for mobilization of cross-class interest groups that can bring pressure to bear to preserve their "spoils" and in the process strengthen programs that have progressive features; and social provision of universal social insurance might beneficially crowd out less egalitarian alternatives. Each of these possibilities, if true, might improve the normative case for a richer mix of universal, as compared with targeted (either conditioned on low income, or functionally targeted at middle- and high-income people through the use of tax-subsidized private-employer-based provision), transfers. These might be reasons enough to put a thumb on the scale for universal social policies, even if no other arguments are offered in their defense.

And yet, the purpose of my inquiry-to explore the question of how a polity might come to politically support social benefits that involve redistribution and also how it might deepen its tolerance for redistribution over time-brings me to the further question of the relationship between welfare state universalism and the attitudes of the mass public towards redistribution. A distinct theme, for example, in Esping-Andersen's work is the idea that different regimes help foster different attitudes about social justice. ${ }^{94}$ If he is right, we would predict that public support for redistribution will vary systematically across states, with higher support in generous, universalistic, welfare

plex question of progressivity of Social Security and Medicare benefits in more detail in Part V.

91 Campbell, note 88, at 129.

92 Id. at $129-30$.

93 Id. at 130.

94 Esping-Andersen, note 69, at 221-29; see also Brooks \& Manza, note 73, at 5-11 (more recent cross-national data suggesting that social preferences with respect to welfare policy are at least partly influenced by pre-existing welfare state institutions). 
states and lower support in liberal regimes. Early empirical efforts to test this hypothesis based on Esping-Andersen's regime-types produced mixed results. ${ }^{95}$ More recent efforts have used more finely specified independent variables (for example, moving away from nation-state ideal types towards specification of policy characteristics), and dependent variables. These more finely specified studies find a more consistent positive relationship between universal welfare programs and public support for redistribution. ${ }^{96}$

The question is, what underlying mechanisms might explain this phenomenon assuming it exists? It seems plausible, indeed probable, that pre-existing "culture" plays a role. At the same time, the evidence discussed earlier of the dialectic relationship between institutions and public behavior suggests that welfare institutions themselves-including their degree of universality-could influence the very legitimacy of economic redistribution in the public consciousness. This would be distinct from the spill-over, interest-group mobilization, and beneficial crowd-out phenomena. If indeed public perception of the legitimacy of spreading economic risks and endowments is endogenous to the design of welfare institutions, how does it work? Here, there is much speculation, but little specification.

At this point, I turn to a parallel literature from psychology and economics on altruism, cooperation, and other-regarding behavior. This area of research enriches our understanding of the micro-foundations of redistributive motivation. Bringing this literature to bear on institutional theories of welfare-state evolution can help us think in more nuanced ways about the conditions under which the public might support redistributional welfare policy, and in particular, whether the degree of universalism might make a difference.

\footnotetext{
95 See Mads Meier Jaeger, Welfare Regimes and Attitudes Towards Redistribution: The Regime Hypothesis Revisited, 22 Eur. Soc. Rev. 157, 157-58 (2006) (reviewing studies).

96 Jason Jordan, Policy Feedback in the Welfare State, An Analysis of Public Support for the Welfare State in 11 States, available at http://papers.ssrn.com/sol3/papers.cfm?abstract_ $\mathrm{id}=1450187$ (finding this relationship when public opinion data disaggregated into distinct policy sectors, and that these attitudes are independent of broader attitudes towards the welfare state, suggesting a positive policy feedback effect of universal programs); Christian Albrekt Larsen, The Institutional Logic of Welfare Attitudes: How Welfare Regimes Influence Public Support, 41 Comp. Pol. Stud. 145, 146-54 (2008); Jaeger, note 95, at 165 (finding this relationship, but also finding that when regime characteristics are broken down into still finer subcategories, for example, degree of cash versus in kind benefits, and level of replacement rate of unemployment benefits, the relationships are less clear-cut); Katerina Linos \& Martin West, Self-Interest, Social Beliefs, and Attitudes to Redistribution: Re-Addressing the Issue of Cross-National Variation, 19 Euro. Soc. Rev. 393 (2003) (introducing demographic variables and other missing data and finding explanations for cross-national variation that are more nuanced but still consistent with a regime-type hypothesis).
} 


\section{Empirical Observations of Other-Regarding Behavior}

While self-interest remains an important-perhaps the predominant-human motivator, altruism is also a distinct motivation that influences human sociality. ${ }^{97}$ This suggests that models of political preferences may be better able to predict behavior with an enlarged conception of motivation. In the next Section I discuss selected research on cognitive foundations of pro-social behavior that, if valid, might lead us to deviate from conventional rational choice predictions about how the public makes policy decisions, particularly with respect to redistribution. I focus on three clusters of phenomena that have particular relevance for the practical problem of designing welfare institutions likely to garner public support: social norms of reciprocity, empathy-altruism and its connection to in-group favoritism, and beliefs about deservingness and their context-dependency.

At the outset, however, the need for caution is paramount when moving from laboratory to the realm of social planning. Experimental studies on motivation can be useful in weeding out bad ideas. ${ }^{98}$ Which among ideas that have not been weeded out should guide policy is a more difficult question and requires an appropriate degree of modesty by scholars seeking to marshal experimental insights in the service of policy design.

Experimental research on other-regarding and pro-social behavior helpfully illuminates the limits of the assumption of exclusively selfinterested rational agency. Rationality appears to encompass a more complex utility function than mainstream economic models presume. Evidence from simple experiments conducted in controlled laboratory settings suggests that individuals do not always act as they should if strictly motivated by self-interest. ${ }^{99}$ One such experiment is the "ultimatum game." 100 In this game, a pair of subjects, the "proposer" and

97 See generally Jane Allyn Piliavin \& Hong-Wen Charng, Altruism: A Review of Recent Theory and Research, 16 Ann. Rev. Soc. 27 (1990); Ernst Fehr \& Klaus M. Schmidt, The Economics of Fairness, Reciprocity and Altruism-Experimental Evidence and New Theories, in 1 Handbook of the Economics of Giving, Altruism and Reciprocity 615 (Serge-Christophe Kolm \& Jean Mercier Ythier eds., 2006); Ernst Fehr \& Herbert Gintis, Human Motivation and Social Cooperation: Experimental and Analytic Foundations, 33 Ann. Rev. Soc. 43 (2007).

98 Colin Camerer \& Eric Talley, Experimental Study of Law, in 2 Handbook of Law and Economics 1619, 1644 (A. Mitchell Polinsky \& Steven Shavell eds., 2007); Edward J. McCaffery \& Joel Slemrod, Toward an Agenda for Behavioral Public Finance, in Behavioral Public Finance 1, 6-7 (Edward J. McCaffery \& Joel Slemrod eds., 2006) [hereinafter Behavioral Public Finance].

99 For reviews, see Fehr \& Schmidt, note 97; Jolls et. al., note 50, at 1489-93.

100 See Werner Guth, Rolf Schmittenberger \& Bernd Schwarze, An Experimental Analysis of Ultimatum Bargaining, 3 J. Econ. Behav. \& Org. 367 (1982); Colin Camerer \& Richard H. Thaler, Anomalies: Ultimatums, Dictators, and Manners, 9 J. Econ Persp. 209 (1995). 
the "responder," must agree on how to divide a sum of money. The proposer can make one proposal as to how to divide the amount. The responder then has the choice of whether to accept or reject the proposal. If the responder accepts it, the players divide the money as proposed. If the responder rejects it, the players forfeit the whole amount.

If we hypothesize that both players are rational and care only about maximizing the amount of money they get, and that the proposer knows that the responder is rational and selfish, we would expect the proposer to offer the smallest amount of money possible. For the responder, any amount of money is better than no money, and for the proposer, such an offer will maximize the amount he gets to keep for himself. This prediction is not borne out. Across hundreds of experiments, the great majority of proposers offer the responder between $40 \%$ and $50 \%$ of the money. 101 Furthermore, offers below $20 \%$ are rejected in $40 \%-60 \%$ of cases. ${ }^{102}$ A common interpretation of these findings, and what responders themselves report, is that responders reject low offers because they feel hurt by an offer they believe to be unfair, and are willing to induce forfeiture - even at a cost to themselves-to express their disapprobation.

It is perhaps easier to explain the proposers' behavior in terms of conventional self-interest. Proposers, anticipating responders' reactions, may be motivated by a self-interested calculation that the responder will reject too low an offer and thus cause forfeiture for both parties. Experiments that compare the ultimatum game with another game called the "dictator game" help to test this hypothesis. The dictator game removes the responder's option to reject; the responder must accept whatever the proposer offers. Self-interest would predict an allocation of zero, but proposers allocate an average of $10 \%-25 \%$ to responders. ${ }^{103}$ The fact that these allocations are lower than in the ultimatum game suggests that at least part of the explanation for proposers' generous offers in the ultimatum game is a fear of forfeiture. But the fact that proposers offer anything at all in the dictator game suggests that pecuniary self-interest is not the entire explanation. It seems at least partly motivated by people's desire to abide by social norms of fairness. ${ }^{104}$

\footnotetext{
101 Guth et al., note 100 , at 371-83.

102 Id.

103 Robert Forsythe, Joel L. Horowitz, N.E. Savin \& Martin Sefton, Fairness in Simple Bargaining Experiments, 6 Games \& Econ. Behav. 347 (1994).

104 A real-world example given by Robert Sugden is the practice of tipping a taxi driver. Even in a one-time interaction where we have no chance of seeing the driver again, we know that the driver expects a tip and that we will feel uneasy if we do not fulfill that
} 
Proposal-response experiments have tended to use students as subjects, controlled laboratory settings, and low stakes. This raises questions about the generalizability of the findings. Subsequent research has found the results robust to fairly large increases in stakes, ${ }^{105}$ and to subjects from varied demographic groups, ${ }^{106}$ and cultures. ${ }^{107}$

Some researchers have hypothesized that the results of the ultimatum game reflect bounded rationality leading to mistakes, and that self-interested actors will learn of their mistakes over repeated games. Simulation experiments do find convergence towards self-interested rational actor predictions over repeat games, but if there is learning, it is very slow indeed; it often takes thousands of iterations before parties' behavior begins to approximate standard predictions-and these are very simple games. ${ }^{108}$

However the fundamental puzzle of the personal utility function might be resolved, there is a significant accumulation of evidence that people in fact are willing to help others and that altruism is at least part of the explanation. It appears, at minimum, that people can have tastes for redistribution together with tastes for maximizing pecuniary self-interest, and that the manifestation of these preferences is influenced by social context.

\section{A. Social Norms of Reciprocity}

Another way to characterize the above observations is that a norm of reciprocity governs and enables coordination in social relations. Although some forms of reciprocity can be seen as consistent with a motive of pure self-interest-by doing something to increase the welfare of others, the giver can expect to be rewarded in turn-it is clear that some reciprocity dynamics incorporate a more complex set of motivations that include people's willingness to be generous or vengeful in response to others' willingness to abide by norms of fairness and other moral norms, even where no gains to self can be expected to result from the reward or punishment behavior. ${ }^{109}$ Trust, or lack of

expectation. Robert Sugden, The Economics of Rights, Co-Operation, and Welfare 155 (1986).

105 See e.g., Lisa A. Cameron, Raising the Stakes in Ultimatum Games: Experimental Evidence from Indonesia, 37 Econ. Inquiry 47 (1999) (replicating effects using stakes as high as three months' income).

106 Fehr \& Schmidt, note 97, at 626 (reviewing studies).

107 Id. at 626-28 (reviewing studies and finding some cultural variation but substantial consistency).

108 Id. at $628-29$.

109 Scholars from different disciplines have converged on parallel concepts, although giving them different names. See, e.g., Sugden, note 104, at 159-61 (contrasting tit-for-tat strategies of experimental game theory based purely in self-interest from conventions of reciprocity based on a moral ethic of cooperation); Samuel Bowles \& Herbert Gintis, The 
trust, in others' willingness to cooperate appears to be vital to reciprocal cooperation. ${ }^{110}$

The "public goods" game further illuminates the importance of reciprocity and trust. In the basic paradigm, subjects are given an initial endowment and told they must secretly choose how much of their allotment to contribute to a common pool. ${ }^{111}$ The experimenter then gives each player an amount proportional to the total contributions to the pool-for example, the pot might be equally split among participants, or the experimenter can multiply that amount to increase each player's return. Each subject thus ends up with whatever amount they kept of their initial endowment plus the additional amount that every player received. A player will do best by contributing nothing, regardless of what other members of the group contribute. Each person in the group will do best, however, if everyone contributes their whole endowment. Experimenters consistently find that although some players contribute nothing, most people make substantial contributions - on average about half of their endowment in the first round.

Over repeat iterations of the public-goods game, the level of contributions gradually decays. Some have suggested that this is consistent with simple self-interest: People only learn over time that they will maximize their gains by contributing nothing. A rival explanation, however, is that most people hate to feel that others are taking advantage of them, and withholding cooperation on subsequent rounds is a way to avoid being (or feeling like) a "sucker" once it becomes apparent that others failed to cooperate in previous rounds. ${ }^{112}$ In related fashion, reducing contributions in subsequent rounds is the only prac-

Evolution of Strong Reciprocity: Cooperation in Heterogenous Populations, 65 Theoretical Population Biology 17 (2004) (contrasting self-interested forms of cooperation that biologists label reciprocal altruism with a form of norm-enforcement and sharing that they term "strong reciprocity"); Dan M. Kahan, The Logic of Reciprocity: Trust, Collective Action, and Law, 102 Mich. L. Rev. 71 (2003) (defining the "logic of reciprocity" as the social process by which when they perceive that others are behaving cooperatively, individuals are moved by honor, altruism, and like dispositions to contribute to public goods even without the inducement of material incentives); Orjan Widegren, Social Solidarity and Social Exchange, 31 Sociology 755, 762-63 (1997) (distinguishing self-interested "social exchange" from "social solidarity," the latter being characterized by group members' willingness to promote the interests of the collective, even without expectations of material gain, provided they perceive similar attitudes among others in the group).

110 Elinor Ostrom, Collective Action and the Evolution of Social Norms, $14 \mathrm{~J}$. Econ. Persp. 137, 146 (2000).

111 For a review of the literature on public-goods experiments, see Marco Janssen \& T.K. Ahn, Adaptation v. Anticipation in Public-Good Games, available at http://www.allac ademic.com/meta/p64827_index.html; John O. Ledyard, Public Goods: A Survey of Experimental Research, in Handbook of Experimental Economics 111-94 (J.H. Kagel \& A.E. Roth eds., 1995).

112 Kahan, note 109 , at 73. 
tical way to punish past noncooperaters. ${ }^{113}$ If the game enables players to punish free-riders without reducing their own contributions in subsequent rounds, players tend to choose direct punishment, even when it is personally costly to do so. ${ }^{114}$ Thus, as in the case of twoplayer proposal-response games, social norms of reciprocity appear to mediate multi-player cooperative behavior: People's willingness to contribute depends on their belief that other people are also contributing. Note, with respect to this as well as the other experimental findings I have discussed in this Part, that the reciprocity dynamic is self-conscious. People are aware that they are engaged with others in a mutually cooperative (or noncooperative) interaction, and this awareness governs their behavior.

A critical question for considering the applicability of these findings to social welfare policy is how the presence of state regulation (as compared with the context of pure private charity) might influence cooperation and generosity. Experimental and field studies have found that the introduction of motives that rival pure voluntary cooperation, for example, material incentives, can cue people that others will not spontaneously cooperate, as well as mask and crowd out people's altruistic dispositions. ${ }^{115}$ If for some people, altruism springs from their desire to demonstrate (to themselves and others) that they are willing to sacrifice material gain for the public good, the introduction of material incentives can undermine motivation. ${ }^{116}$ Once some people stop sacrificing for the greater good, reciprocity dynamics may lead others to stop, and so on, ad infinitum, until the cooperative equilibrium breaks down. This might lead one to conclude that cooperative norms can only evolve in the absence of incentives (or state mandates). As it turns out, this is not so. The selective use of incentives might actually maximize cooperation. "Targeted retaliation"-a regulatory system that simultaneously assures the public that most people are cooperators, but also that the minority of people who are noncooperators will be penalized-avoids the cueing, masking, and motivational crowd-out effects associated with across-the-board in-

113 See Ernst Fehr \& Simon Gaechter, Cooperation and Punishment in Public Goods Experiments, 90 Am. Econ. Rev. 980 (2000) (describing experimental evidence); Bowles \& Gintis, note 109, (describing ethnographic evidence).

114 Fehr \& Gaechter, note 113, at 984-86; J. Andreoni, Cooperation in Public Goods Experiments: Kindness or Confusion?, 85 Am. Econ. Rev. 891 (1995).

115 Kahan, note 109 , at 76-77. A classic demonstration of this situation is Richard $M$. Titmuss, The Gift Relationship: From Human Blood to Social Policy (Ann Oakley \& John Ashton eds., New Press 1997) (1970) (finding people more willing to donate blood when asked to volunteer than when offered payment).

116 Kahan, note 109 , at 76-77. 
centive regimes, while at the same assuring cooperators that they will not be exploited. ${ }^{117}$

In sum, behavior in experimental social dilemmas suggests that people are willing to be generous, even to strangers, and even at personal cost, and that their generosity is influenced by expectations of others' cooperation and adherence to social norms.

\section{B. Empathy-Altruism and In-Group Favoritism}

The social psychology iiterature typically distinguishes between norms of fairness, which have been the focus of the discussion thus far, and empathy-altruism. ${ }^{118}$ Social norms create a benchmark against which people judge the actions and motives of others. Empathy-altruism provides no benchmark; instead it provides a partial identification with another's welfare.

Social cognition is made possible through the learned human capacity to take the perspective of others. ${ }^{119}$ Perspective-taking might take the form of true identification or empathy with another-mentally imagining oneself to be the other-but absent a fair degree of knowledge about the other person, this may be difficult or impossible. ${ }^{120}$ More commonly, people take the perspective of others by "projection," that is, imagining what oneself would have done and thought if put in the role of the other. ${ }^{121}$ As a judgmental heuristic, self-projection enables people to make predictions about others that are often accurate. ${ }^{122}$

Both forms of social cognition can give rise to pro-social behavior. Just as effective responses to others' adherence to social norms drive individuals to reward or punish them, so too can empathy in response to the needs or distress of others drive individuals to help (or decline to help). Here, as before, researchers debate whether what appears to

117 Id. at 79-80 (making this argument), 80-98 (offering examples that include regulating tax compliance, securing local public support for siting public facilities such as hazardous waste dumps, and encouraging the sharing of creative ideas and technology); see also Samuel Bowles \& Sung-Ha Hwang, Social Preferences and Public Economics: Mechanism Design when Social Preferences Depend on Incentives, 92 J. Pub. Econ. 1811, 1815-18 (2008) (modeling optimal explicit incentives in the presence of both crowding in and crowding out, and discussing the example of sanctions for noncooperators in public goods settings as a way to enhance civic-minded behavior).

118 E.g. Louis Lévy-Garboua, Claude Meidinger \& Benoît Rapoport, The Formation of Social Preferences: Some Lessons from Psychology and Biology, in Handbook of the Economics of Giving, note 97 , at 545, 595.

119 Id. at $573-81$.

120 Id. at 574.

121 Id. at $574-75$.

122 Note, however, that the egocentric foundation of the heuristic may lead people to overestimate the extent to which others have the same beliefs, the so-called "false consensus effect." Id. at 576. 
be other-regarding behavior truly reflects pure altruism. For example, voluntarily helping someone in need might reflect a truly empathic, other-oriented response, or it may reflect an egoistic desire to reduce personal distress induced by seeing another in distress. ${ }^{123}$ Nevertheless, an egoistic explanation of the motivation to relieve others' distress does not explain away the underlying existence of distress at another's hardship. Regardless of the precise mix of egoism and altruism that drives it, the fact remains that some portion of the population can be motivated to help others without promise of material reward.

The cognitive mechanism of self-projection carries over to the group level. "Social identity theory" posits that people's identity is significantly organized around their membership in salient groups. ${ }^{124}$ People are more likely to project onto others who are in their own social group than they are onto people from different groups. ${ }^{125}$ Selfanchoring may lead them to reason that similar others will think and behave more like themselves than dissimilar others. ${ }^{126}$ The use of the self-projection heuristic at the group level gives rise to a number of social phenomena. People perceive more cohesion, expect more reciprocal behavior, and are, in turn, likely to be more generous and cooperative towards members of an in-group. ${ }^{127}$

Importantly, social groups can be defined in different ways-they can be defined narrowly, at the level of classmate or neighborhood, or more broadly, at the level of nation. Any given person will belong to multiple groups, and membership in a particular group will have salience in some contexts but not others. This phenomenon can be morally problematic; indeed, much of the literature on groupism has focused on its role in the formation of racist attitudes. U.S. benevolent societies, which created some of the first forms of social insurance, were premised on the formation of an identity that excluded those outside the brotherhood of members. ${ }^{128}$ A key finding of the research, however, is that group status is mutable: In-group favoritism can be altered depending on the level at which groups and social cate-

123 See, e.g., Robert B. Cialdini, Mark Schaller, Donald Houlihan, Kevin Arps, Jim Fultz \& Arthur L. Beaman, Empathy-Based Helping: Is It Selflessly or Selfishly Motivated?, 52 J. Personality \& Soc. Psychol. 749 (1987) (offering experimental data of an egoistic motive of distress reduction).

${ }^{124}$ Henri Tajfel \& John C. Turner, The Social Identity Theory of Intergroup Behavior, in Psychology of Intergroup Relations 7, 15-19 (Stephen Worchel \& William G. Austin eds., 2d ed. 1986).

125 Jordan M. Robbins \& Joachim I. Krueger, Social Projection to Ingroups and Outgroups: A Review and Meta-Analysis, 9 Personality \& Soc. Psychol. Rev. 32, $38-41$ (2005).

126 See Lévy-Garboua et al., note 118, at 589.

127 See id. at 593-94; see Robbins \& Krueger, note 125, at 43-44.

128 See generally Brian J. Glenn, Understanding Mutual Benefit Societies, 1869-1960, 26 J. Health Pol., Pol'y \& L. 638, 644-45 (2001). 
gories are made salient. ${ }^{129}$ This has important implications for policy, which I develop in more detail in Part VI.

\section{Beliefs About Deservingness and the Context-Dependency of Social Preferences}

People express stronger support for redistribution if they believe that the recipient's need is caused by circumstances beyond his or her control.130 In surveys, people express stronger support for social transfers if they are told that the recipient's hardship is caused by disability, for example, and less generous if told that the recipient is not looking for work, or is picky about which work to accept. ${ }^{131}$ In dictator games, proposers give about three times as much when they are told the recipient is the American Red Cross than when the subject is anonymous, and when told the recipient is a welfare recipient, give significantly more if also told the subject has expressed a strong interest in working than if told the recipient has expressed only a weak preference for working. ${ }^{132}$ Cross-national studies have found a fairly consistent pattern consonant with the idea that locus of control is important to people. Those deemed most "deserving" across cultures tend to be the elderly, followed by the sick and disabled, followed by needy families with children and the unemployed. ${ }^{133}$ Able-bodied individuals on public assistance are fairly consistently seen as the least deserving group. ${ }^{134}$

Beliefs about the causes of poverty are also important to support for redistribution. At a societal level, people who believe in structural explanations (discrimination, bad economy, inadequate schools) or fatalistic explanations (bad luck) for poverty are more likely to support

129 Samuel L. Gaertner, Jeffrey Mann, Audrey Murrell \& John F. Dovidio, Reducing Intergroup Bias: The Benefits of Recategorization, in Intergroup Relations: Essential Readings 356, 356 (Michael A. Hogg \& Dominic Abrams eds., 2001); Penelope J. Oakes, S. Alexander Haslam \& John C. Turner, Stereotyping and Social Reality 147-51 (1994) (reviewing studies on the role of context, or frame of reference, in self-categorization); Robbins \& Krueger, note 125 , at 42 .

130 Jeffry A. Will, The Dimensions of Poverty: Public Perceptions of the Deserving Poor, 22 Soc. Sci. Res. 312, 329-30 (1993) (polling U.S. subjects); Wim van Oorschot, Who Should Get What, and Why? On Deservingness Criteria and the Conditionality of Solidarity Among the Public, 28 Pol'y \& Pol. 33, 38-39 (2000) (polling Dutch subjects, whether the recipient had control over his needy status was the most significant factor among several in its influence on support for welfare transfers).

131 Will, note 130 , at 329 .

132 Christina M. Fong, Samuel Bowles \& Herbert Gintis, Strong Reciprocity and the Welfare State, in 2 Handbook of the Economics of Giving, note 97, at 1439, 1448.

133 E.g., Richard M. Coughlin, Ideology, Public Opinion, and Welfare Policy: Attitudes Toward Taxes and Spending in Industrialized Societies 117-20 (1980); see also Larsen, note 96 , at 149.

134 Larsen, note 96, at 149. 
redistributive policies than people who believe poverty is caused by individual effort (or lack thereof). ${ }^{135}$ Psychologists have labeled the latter construct a belief in a "just world": the idea that people "get what they deserve and deserve what they get."136 Moreover, individuals who have a strong belief in a just world may systematically interpret what they observe so as to preserve this belief, making it difficult to dislodge. ${ }^{137}$ The literature on this subject is large, but three observations seem particularly relevant to the present inquiry.

First, belief in a just world is not merely a proxy for self-interest. Personal income influences people's explanations for poverty: Lowincome people are more likely than middle-class people to attribute poverty to structural factors or luck rather than individualistic factors, and high-income people have stronger-than-average beliefs in the role of self-determination. ${ }^{138}$ The poor are also the strongest supporters of redistribution, and the well-off its strongest opponents. ${ }^{139}$ In light of

135 See, e.g., Christina Fong, Social Preferences, Self-Interest, and the Demand for Redistribution, 82 J. Pub. Econ. 225, 232, 234 tbl.2 (2001); Gregory Mitchell, Philip E. Tetlock, Barbara A. Mellers \& Lisa D. Ordónez, Judgments of Social Justice: Compromises Between Equality and Efficiency, 65 J. Personality \& Soc. Psychol. 629, 635-37 (1993) (finding that rather than having a stable set of preferences-for example, either egalitarian or meritocratic-experimental subjects' beliefs about how to set an income distribution in a hypothetical society depended on whether they were told that rewards were tightly or loosely linked with effort in that society).

136 Lauren D. Appelbaum, Mary Clare Lennon \& J. Lawrence Aber, When Effort Is Threatening: The Influence of the Belief in a Just World on Americans' Attitudes Toward Antipoverty Policy, 27 Pol. Psychol. 387, 390 (2006). See generally Melvin J. Lerner, The Belief in a Just World: A Fundamental Delusion (1980); Responses to Victimizations and Belief in a Just World (Leo Montada \& Melvin J. Lerner eds., 1998); Roland Bénabou \& Jean Tirole, Belief in a Just World and Redistributive Politics, 121 Q.J. Econ. 699 (2006); Claudia Dalbert, Coping with an Unjust Fate: The Case of Structural Unemployment, 10 Soc. Just. Res. 175 (1997); Zick Rubin \& Letitia Anne Peplau, Who Believes in a Just World?, J. Soc. Issues, Summer 1975, at 65.

137 See, e.g., Appelbaum et al., note 136, at 397-98 (using a vignette involving a poor mother trying to improve her situation, found that survey respondents with a strong belief in a just world were paradoxically less likely to support public aid for the mother the more effort she made; authors interpreted this as the participants' effort to reconcile a challenged belief system, that is, a woman who is making efforts but still cannot get ahead); Charity Scott, Belief in a Just World: A Case Study in Public Health Ethics, Hastings Center Rep., Jan./Feb. 2008, at 16 (drawing similar conclusions from a case study of negative reader reactions to an Atlanta newspaper article describing a struggling low-income family that received benefits under Georgia's state children's health insurance program). See generally Bénabou \& Tirole, note 136, at 705-06 (reviewing studies in both laboratory and natural settings).

138 Heather E. Bullock, Attributions for Poverty: A Comparison of Middle-Class and Welfare Recipient Attitudes, 29 J. Applied Soc. Psychol. 2059, 2066-68 (1999) (finding welfare recipients more likely than middle-class respondents to attribute poverty to structural rather than individualistic factors); Fong, note 135, at 232-33 (finding high-income sample of people had stronger average beliefs that self-determination rather than luck causes poverty than the general population).

139 Martin Gilens, Why Americans Hate Welfare: Race, Media, and the Politics of Antipoverty Policy 52-54 (1999); Yeheskel Hasenfeld \& Jane A. Rafferty, The Determinants of 
these parallels, it seems plausible that beliefs about the causes of poverty, and therefore desert, are simply justificatory constructs that replicate people's underlying self-interested motives with respect to redistribution.

As it turns out, the correlation between personal income and beliefs about the causes of poverty is quite imperfect: A large fraction of the poor oppose income redistribution and a large fraction of the rich support it. ${ }^{140}$ This implies that people may have beliefs about the causes of poverty and deservingness that are independent of material selfinterest. One way to test this hypothesis is to measure the strength of the relationship between people's support for redistribution and their beliefs about the causes of poverty while controlling for income and other factors that may be proxies for self-interest. Several studies that have endeavored to do this have found respondents' beliefs robust to controls for self-interest. ${ }^{141}$ In other words, self-interest alone cannot explain people's beliefs about the causes of poverty.

Second, the public is heterogeneous in strength of belief in a just world. Much is made of the fact that in the United States, individualistic, "personal responsibility"-oriented explanations for poverty tend to prevail over structural or fatalistic explanations. ${ }^{142}$ However, structural or fatalistic beliefs about the causes of poverty also exist among Americans, and this may help explain other core commitments Amer-

Public Attitudes Toward the Welfare State, 67 Soc. Forces 1027, 1041-42 (1989) (finding socioeconomically vulnerable groups more likely than others to support means-tested welfare programs and concluding that self-interest plays an important role in welfare attitudes).

${ }^{140}$ Fong et al., note 132 , at $1441-42$ (reporting based on survey data that $24 \%$ of respondents with income of at least $\$ 150,000$ say that government should "redistribute wealth by heavy taxes on the rich," and that among respondents with incomes below $\$ 10,000$ and who do not expect their situation to improve in the next five years, $32 \%$ say that government should not redistribute wealth with heavy taxes on the rich, and $23 \%$ say that poor people should help themselves rather than having the government "make every possible effort to improve the ... position of the poor").

141 E.g., Giacomo Corneo \& Hans Peter Grüner, Individual Preferences for Political Redistribution, 83 J. Pub. Econ. 83, 106 (2002) (regression analysis of international survey data consistent with hypothesis that preferences for government redistribution are driven only partly by selfish pecuniary incentives and that beliefs about the link between individual effort and social standing, as well as social rivalry, also significantly influence preferences); Fong, note 135, at 236-37, 242 (finding highly significant the effect of beliefs about the role of self-determination and exogenous-determination on poverty on support for redistribution, controlling for income and various other proxies for self-interest), 240-41 (finding these beliefs robust to controls for the incentive effects of taxation).

142 E.g., Joe R. Feagin, Subordinating the Poor: Welfare and American Beliefs 93-97 (1975); James R. Kluegel \& Eliot R. Smith, Beliefs About Inequality: Americans' Views of What Is and What Ought to Be 78 (1986); see also Alberto Alesina, Edward Glaeser \& Bruce Sacerdote, Why Doesn't the United States Have a European-Style Welfare State?, 2 Brookings Papers on Economic Activity 187 (2001) (contrasting European and American beliefs about reasons for poverty and their relationship to attitudes about redistribution). 
icans persistently express - the values of egalitarianism (equality of opportunity, treatment, and status) and humanitarianism (the belief that we have an ethical obligation to help those in need). ${ }^{143}$ Most Americans hold some mix of these core values, leading to a fundamental ambivalence in forming attitudes about redistribution. ${ }^{144}$ People may feel a desire to help the poor, for example, but also feel that the poor should take some personal responsibility for overcoming their misfortune.

Third, people's beliefs about a just world and corollary beliefs about redistribution are context-dependent. It is well established that people will express different social preferences depending on how an issue is presented or "framed." 145 Consonant with this phenomenon, people's preferences may depend on which core values are "activated" or cued when they are asked to make a judgment. References to "welfare" elicit particularly negative reactions. Martin Gilens, in a study of U.S. attitudes toward welfare policies, found that most Americans say they favor increased government spending on the welfare state and think that the government is not doing enough to help the poor. ${ }^{146}$ However, when asked about welfare-in particular, meanstested cash transfers to the able-bodied, working-age poor-and "welfare recipients," Americans' attitudes are much more negative. ${ }^{147}$ Gilens' interpretation of this apparent paradox is that it is driven prin-

${ }^{143}$ See Stanley Feldman \& Marco R. Steenbergen, The Humanitarian Foundation of Public Support for Social Welfare, 45 Am. J. Pol. Sci. 658, 673-74 (2001) (contrasting the effects of egalitarian and humanitarian views on individuals' support of different types of welfare states).

144 James H. Kuklinski, Citizens and Politics: Perspectives from Political Psychology 364-65 (2001); Erin O'Brien \& Joe Soss, Public Opinion, in 2 Poverty in the United States: An Encyclopedia of History, Politics, and Policy 601, 601-04 (Gwendolyn Mink \& Alice O'Connor eds., 2004); Stanley Feldman \& John Zaller, The Political Culture of Ambivalence: Ideological Responses to the Welfare State, 36 Am. J. Pol. Sci. 268, 268 (1992).

145 See generally McCaffery \& Slemrod, note 98, at 7-12; Thaler \& Sunstein, note 7; Yoram Amiel, Frank Cowell, Liema Davidovitz \& Avraham Polovin, Preference Reversals and the Analysis of Income Distributions, 30 Soc. Choice \& Welfare 305 (2008); Jon Hanson \& David Yosifon, The Situational Character: A Critical Realist Perspective on the Human Animal, 93 Geo. L.J. 1, $42-43$ (2004); Daniel Kahneman, A Perspective on Judgment and Choice: Mapping Bounded Rationality, 58 Am. Psychologist 697, $702-03$ (2003) (describing his research with Amos Tversky in the 1970's and 1980's that illustrated the effects of framing).

146 Gilens, note 139, at 2. A more recent study found that Americans of all income levels dramatically underestimate the degree of wealth inequality in the United States, and when asked to construct an "ideal" distribution, choose a distribution that is much more egalitarian than the current distribution in the United States. Michael I. Norton \& Dan Ariely, Building a Better America-One Wealth Quintile at a Time, 6 Persp. on Psychol. Sci. 9 (2011).

147 Gilens, note 139 , at $61-67$. 
cipally by people's beliefs about the deservingness of the people they think receive welfare. ${ }^{148}$

More particularly, Gilens argues that media discourse on poverty and welfare in the 1960's created an exaggerated linkage between African-Americans and poverty, and that this media frame remains highly salient in the American public imagination, powerfully influencing attitudes towards welfare. ${ }^{149}$ Today, people overestimate the proportion of welfare recipients who are African-American, and they equate African-Americans who receive welfare with a lack of commitment to the work ethic. ${ }^{150}$ In essence, according to Gilens, people's beliefs about the deservingness of welfare recipients are associated with stereotypes about the race of welfare recipients and the work ethic of African-Americans. ${ }^{151}$

Research on the use of opposing media frames in mobilizing public support (or opposition) finds that on average, support for social spending is significantly higher when described in ways that emphasize "responsible economic planning," rather than appealing to people's compassion and sympathy for the poor. ${ }^{152}$ Personal narratives of the able-bodied poor may trigger negative reactions in people who have strong beliefs in a just world, and who may interpret the person's failure as reflecting a lack of personal responsibility. ${ }^{153}$ By contrast, frames that emphasize structural economic challenges facing the nation, values of responsibility, independence, stewardship, and the collective responsibility of the citizenry, have been found effective in eliciting support for social spending. ${ }^{154}$

To summarize this Part, people will be generous to others in ways that cannot always be explained in terms of simple accounts of selfinterest, but their willingness to be generous is conditional on their belief in others' compliance with social norms, and is influenced by

148 Id.

149 Id. at 102-32; see also Shanto Iyengar, Is Anyone Responsible?: How Television Frames Political Issues 46-68 (1991) (describing how the ways in which poverty is presented on television significantly influences the causal attributions viewers make).

150 Gilens, note 139, at 68-69; see also Alesina et al., note 142, at 28-33 (arguing that Americans' reluctance to support redistributive policies compared with Europeans' is significantly linked with racial heterogeneity in the United States, the racial animosity of many Americans, and the belief by most Americans that redistribution favors racial minorities).

151 Gilens, note 139, at 77-79; see also Jon Hanson \& Kathleen Hanson, The Blame Frame: Justifying (Racial) Injustice in America, 41 Harv. C.R.-C.L. L. Rev. 413, 444-47 (2006) (developing idea of a "blame frame" within which Americans justify racism based on a combination of belief in a just world and belief that people, including victims, are free to choose and bear responsibility for their choices).

152 Matthew C. Nisbet, Communicating About Poverty and Low-Wage Work: A New Agenda 15-19 (2007), http://www.inclusionist.org/files/USUKPaper.pdf.

153 See, e.g., Scott, note 137.

154 Nisbet, note 152 . 
their capacity to empathize or take the perspective of others, by their belief in the relationship between effort and reward, and by the context in which their preferences are elicited. A key observation is that people are heterogeneous in the extent and manner in which these different factors influence their motives and beliefs, and thus an important challenge for institutional design, assuming the normative goal of facilitating vertical redistribution, is to find a way to enable other-regarding preferences to dominate.

In particular, we might take into account:

Reciprocity. Where cooperation is required, cooperation by other participants matters a great deal to people's willingness to contribute. The ability to selectively punish (or reward) others based on their compliance with norms of fairness can facilitate trust and cooperation.

Empathy-Altruism and Groupism. People tend to empathize or identify more with people they perceive as belonging to their own group, and will be more generous to people in their own group. Group identification, however, can cut across many dimensions, and which dimensions will be most salient at a given time depends on context.

Beliefs about Deservingness and the Importance of Context. People express stronger support for redistribution if they believe that the poverty is caused by circumstances beyond the recipient's control. People's beliefs about desert, and hence redistribution, are influenced by context and by how an issue is presented.

\section{Lessons for Program Design}

This Part considers how we might marshal the richer motivational account developed in Part $\mathrm{V}$ for thinking about program design where redistribution is one's goal. I do so by further developing the ideas in the general context of social insurance, and then by offering an extended illustration in one area of current social policy change-paid family leave-of how we might develop an agenda for research that would evaluate the validity of my thesis.

If reciprocity theory is correct, individuals' willingness to contribute to a program depends on the cooperation of other participants (or at least the perception thereof). People might signal their cooperation through financial contributions, or by some past behavior that indicates that they have conformed to relevant social norms in a way that makes them trustworthy. Social insurance, by the very nature of its facial universality of taxes and spending-most everyone contributes, 
and most everyone can become eligible for benefits ${ }^{155}$-comports more readily with reciprocity ideals than a program that taxes some citizens and transfers benefits to others. Distribution of benefits conditional on low income is more difficult to square with reciprocity ideals absent the incorporation of additional features designed to make members of the target group "earn" the entitlement to benefits. ${ }^{156}$ The thesis I wish to advance is that redistribution may be easier to achieve in some instances if built into a tax-and-transfer scheme that has reciprocity-like features.

Popular opinion polls consistently find that people prefer payroll taxes to other kinds of taxes, including income taxes and property taxes. ${ }^{157}$ This arguably flows from the reciprocity-like features of programs financed with payroll taxes. Payroll taxes are structured as a fixed percentage of earnings, often with a ceiling on the wage base that is taxed. They typically have an earmarked purpose, thus creating a link (or perceived link) between contribution and benefits that is lacking with programs financed by direct spending from general revenues. ${ }^{158}$ Payroll taxes are less progressive than income taxes, how-

155 As noted earlier, a social insurance scheme can be designed in such a way as to make eligibility difficult (for example, stringent workforce attachment requirements), and this may be problematic as a matter of equity, especially for those who are involuntarily unemployed or underemployed. See Part II. My point here is that as a facial matter all who contribute and "play by the rules" (including by staying sufficiently attached to work) are eligible for benefits, and this relationship of reciprocity within the institutional design is an important element of its psychological appeal.

156 Wax, note 16, at $270-74$ (arguing that proposals advocating unconditional rights to cash welfare benefits face popular resistance because they run counter to social norms of reciprocity, and that work requirements satisfy participants' expectation that beneficiaries are contributing by making an effort to improve their situation).

157 Andrea Louise Campbell \& Kimberly J. Morgan, Financing the Welfare State: Elite Politics and the Decline of the Social Insurance Model in America, 19 Stud. Am. Pol. Dev. $173,184-85$, figs. 2 \& 3 (2005). To the extent I discuss taxation, I treat it as one side of the two-sided tax/expenditure coin that is part of any program of social welfare benefits. There is, however, a rich and sophisticated literature on the psychology and political economy of taxes as a distinct matter, intimately linked with the questions I explore, and part of the larger conversation about the formation of social preferences of which this Article is a piece. For a few examples of the literature to which I refer, see Sven Steinmo, Taxation and Democracy: Swedish, British and American Approaches to Financing the Modern State (1993); Harold L. Wilensky, Rich Democracies: Political Economy, Public Policy, and Performance (2002); Edward J. McCaffery \& Jonathan Baron, Thinking About Tax, 12 Psychol. Pub. Pol'y \& L. 106 (2006); Kimberly J. Morgan, Constricting the Welfare State: Tax Policy and the Political Movement Against Government, in Remaking America, note 88 , at 27.

158 See, e.g., Benjamin I. Page \& Robert Y. Shapiro, The Rational Public: Fifty Years of Trends in Americans' Policy Preferences 118-25 (1992) (contrasting high and stable public support over time for spending on Social Security, with consistently low support for spending on welfare, and arguing that an important reason for this is that Social Security "actually or potentially includ[es] most of the population" as beneficiaries); C. Eugene Steuerle \& Jon M. Bakija, Retooling Social Security for the 21st Century: Right and Wrong Approaches to Reform 25-27 (1994) (noting that the "earned right" feature of Social Security 
ever-indeed, they may be regressive-not only because of the absence of progressivity in the rate structure, but also because of the common (but not universal) practice of capping the taxable wage base, and the fact that payroll taxes tax only earned income. For this reason, in a program financed by payroll taxes, any desired progressivity is usually accomplished on the benefits side of the equation. The ratio of contributions to benefits is a matter of program design and can lead to more or less progressivity.

Take, for example, the case of Social Security. The payroll tax that finances the program-while functionally universal-is almost certainly regressive: It imposes a flat tax (around $12 \%$ ) on payroll, ${ }^{159}$ but the marginal tax rate is zero for any wages that exceed the Social Security taxable wage base (of just under $\$ 107,000$ ). ${ }^{160}$ Nonetheless, the combined tax and benefits structure is progressive. The formula for calculating Social Security benefits is weighted so that low earners receive a higher proportion of their preretirement earnings than high earners. ${ }^{161}$ In addition, a floor on benefits operates to redistribute to low earners. ${ }^{162}$ The net result is that individuals paying in the bottom decile of total lifetime Social Security taxes receive about $17 \%$ of total lifetime benefits, while individuals paying in the top decile receive only about $6 \%$ of total lifetime benefits. ${ }^{163}$ The increased generosity of Social Security benefits in the post-World War II period had a dramatic effect in reducing poverty among the elderly-a combined result, presumably, of its role in mandating intergenerational crosssubsidies and its progressivity. ${ }^{164}$

likely increased popular support); Campbell \& Morgan, note 157, at 174-75 (arguing that social insurance programs have proven popular in advanced industrial states because of the link they create between contributions and entitlement); Paul M. Romer, Preferences, Promises, and the Politics of Entitlement, in Individual and Social Responsibility: Child Care, Education, Medical Care, and Long-Term Care in America 195, 198-200, 213-17 (Victor R. Fuchs ed., 1996) (arguing rational choice assumptions of political preferences that reflect self-interest cannot fully explain the popularity of social insurance compared with means-tested transfers, and theorizing that the former's popularity can be explained by the sense of entitlement that benefits perceived as "earned" give citizens to punish politicians who attempt to retrench benefits in future periods).

159 IRC $\$$ 3101(a), 3111(a).

160 U.S. Soc. Sec. Admin., Fact Sheet: Social Security, 2011 Social Security Changes, http://www.ssa.gov/pressoffice/factsheets/colafacts2011.pdf.

16142 U.S.C. $\S 415(\mathrm{a})(1)(\mathrm{A})(2006)$.

16242 U.S.C. $\$ 415(\mathrm{a})(1)(\mathrm{C})(2006)$.

163 Andrew G. Biggs, Mark Sarney \& Christopher Tamborini, U.S. Soc. Sec. Admin., A Progressivity Index for Social Security, Issue Paper No. 2009-01, 11 tbl.1 (Jan. 2009), http:// www.ssa.gov/policy/docs/issuepapers/ip2009-01.pdf.

164 Gary V. Englehardt \& Jonathan Gruber, Social Security and the Evolution of Elderly Poverty, in Public Policy and the Income Distribution, note 55, at 259, 280-82, 285 (analysis finding substantial declines in fraction of elderly households and families below the federal poverty level between 1967 and 2000 and arguing that it can be explained entirely by increases in Social Security benefits during that time). 
Social Security remains very popular. ${ }^{165}$ It is possible that the broad "extensive margin" (that is, reach of participation) of the program has played an important role in catalyzing mutual support by citizens. It is also, of course, possible that support for Social Security is premised in part on citizens' mistaken belief that the program is not actually redistributing income. ${ }^{166}$ It is noteworthy, however, that until recently, social scientists believed it was more progressive than it is. ${ }^{167}$ To the extent that expert beliefs trickle into the public consciousness, the "false premise" conjecture is weakened. Still, the possibility begs the overarching normative question of whether I would advocate policies that achieve redistribution by, in essence, misleading citizens into believing that a program is less redistributional than it is. The answer is no: To advocate such a position is troubling from the perspective of democratic legitimacy.

165 See Fay Lomax Cook \& Meredith B. Czaplewski, Public Opinion and Social Insurance: The American Experience, in Social Insurance and Social Justice: Social Security, Medicare, and the Campaign Against Entitlements 251, 258-62 (Leah Rogne, Carroll L. Estes, Brian R. Grossman, Brooke A. Hollister \& Erica Solway eds., 2009) (citing data from multiple national public opinion polls finding very strong bipartisan support for the purpose of Social Security despite concern about its solvency).

166 Although researchers have revealed ways in which people misunderstand some aspects of Social Security, I have been unable to find a study that directly tests whether public support for the program depends on a perception that the program is nonredistributional. Cf. Howell E. Jackson, Accounting for Social Security Benefits, in Behavioral Public Finance, note 98, at 261, 266-75 (arguing that the combination of a confusing benefit disclosure form and cognitive biases leads Social Security beneficiaries to underestimate the value of their participation in Social Security and the extent of their benefits).

167 Challenges to an earlier consensus view as to the progressivity of Social Security have emerged in the past decade. The reexamination was prompted in part by a wellknown study that suggested that simply comparing the replacement rates of wealthy and poor recipients may be misleading because the greater longevity of wealthy people will tend to offset their lower replacement rates. See Jeffrey B. Liebman, Redistribution in the Current U.S. Social Security System, in The Distributional Aspects of Social Security and Social Security Reform 11, 12 (Martin Feldstein \& Jeffrey B. Liebman eds., 2002). However, more recent studies using a broader array of methods and taking into account a range of offsetting factors-longevity as well as others-suggest that Social Security is still quite income-redistributional. Biggs et al., note 163; Noah Meyerson \& John Sabelhaus, Cong. Budget Office, Is Social Security Progressive?, Economic and Budget Issue Brief (Dec. 15, 2006), http://www.cbo.gov/ftpdocs/77xx/doc7705/12-15-Progressivity-SS.pdf; C. Eugene Steuerle, Adam Carasso \& Lee Cohen, Urban Inst., How Progressive Is Social Security and Why? (May 2004), http://www.urban.org/UploadedPDF/311016_Straight37.pdf. There is also a lively debate about the progressivity of Medicare. Compare Kathleen McGarry, Inter- and Intra-Generational Aspects of Medicare, Gerontological Soc'y of Am. Int. Group Newsl. (Gerontological Soc'y of Am., Washington, D.C.), Fall 2002 (finding that Medicare redistributes across groups in a variety of ways but disproportionately benefits higher-income relative to lower-income individuals), with Jay Bhattacharya \& Noshir Lakdawalla, Does Medicare Benefit the Poor?, 90 J. Pub. Econ. 277, 277, 287-90 (2006) (arguing that Medicare is an "extraordinarily progressive public program," and that previous research concluding the contrary has used inadequate proxies for economic disadvantage), and Campbell, note 88, at 129 (characterizing Medicare as progressive). 
At the same time, it is not obvious to me that citizen awareness of the precise distributional features of Social Security or any other universal program is critical to the legitimacy of consent. For example, if people support redistribution within Social Security because they do not know where they sit in the distribution-whether they will be beneficiaries or not-their consent is no less legitimate. This Article does not advance a theory of distributive justice, but many people would judge as highly legitimate a system in which people supported redistribution behind a proverbial "veil of ignorance" as to whether they would be a net payer or beneficiary. Another possibility is that people are unaware of the redistributional features of Social Security simply because they have stopped scrutinizing where they fall in the distribution. Neither does this strike me as a bad thing. There is a difference between a person who fails to understand because information is withheld and one who fails to understand because she trusts the system.

People may also have more confidence in a social welfare program in which cooperation and defection can be monitored, as well as rewarded or punished. ${ }^{168}$ The kinds of behavior that might serve as a signal of cooperation would vary depending on the purpose of the program. An easy example is veterans' benefits, which can be seen as a reward for past service to one's country. ${ }^{169}$ For other programs, however, ex ante cooperation may be harder to demonstrate and checks on over-use of benefits therefore might be more important as a device for satisfying reciprocity norms. Involuntary unemployment, for example, might easily be mistaken for shirking. Unemployment insurance benefits are conditioned on a minimal pre-unemployment work history, proof of discharge without fault, and continuing efforts by the recipient of benefits to search for a new job. ${ }^{170}$ These criteria of initial and continuing eligibility might be intended as proxies, however imperfect, for cooperation with the system of mutual insurance.

Lessons about groupism and framing might also be incorporated into program design. As noted earlier, group status is mutable and context-dependent. ${ }^{171}$ A person's membership in a particular group can be made more salient in some contexts, and less so in others. Perceptions of group status, in turn, can influence people's support of welfare policies. ${ }^{172}$ Framing a social problem around risks that are

168 Bo Rothstein, Social Traps and the Problem of Trust 19-26 (2005).

169 See Campbell, note 83, at 130 (providing evidence that recipients of veterans' benefits programs contribute at a greater rate than those of non-means-tested programs).

170 See, e.g., N.Y. Labor Law §§ 591, 593 (McKinney 2002 \& Supp. 2011).

171 See note 129 and accompanying text.

172 Gilens, note 139, at 60-79; Erzo F.P. Luttmer, Group Loyalty and the Taste for Redistribution, $109 \mathrm{~J}$. Pol. Econ. 500, 501 (2001) (finding individuals increase their support for welfare spending as the share of local recipients from their own racial group rises). 
common across income groups-for example, vulnerability to job loss in a bad economy, risk of unexpected illness, or the difficulty of balancing work and family care-might not only make common life-cycle risks more salient, but also reduce the salience of perceived "taxpayer" versus "beneficiary" group status.

Designing a program of targeted benefits requires deciding the dual questions of which citizens belong in the needy group, and how much they need. Political theorist Bo Rothstein argues that the very act of deciding these "boundary" questions creates a moral logic that singles out some citizens as socially inferior, "maladjusted," or "other," and thereby undermines egalitarian principles. ${ }^{173}$ Public debate over these questions can very quickly devolve into questions about which poor are "deserving" and which are not. ${ }^{174}$ Under a more universal system, by contrast, these boundary questions largely dissolve and the moral logic changes: "The question becomes not "how shall we solve their problem?' but rather 'how shall we solve our common problem. .. ?" "175

Drawing on the analysis in Part IV, Rothstein's "moral logic" might be reformulated in terms of its cognitive logic: Universal provision might ameliorate the potentially distorting effects of groupism, related assessments of deservingness, and distrust-based resistance to forms of cooperation that might otherwise activate altruism. Recalling that people are more generous towards people they perceive to be in their own group, programs that target benefits selectively may dampen public generosity. The necessity of policing the boundaries of a means-eligibility threshold could serve to sharpen the public's focus on "fraud and abuse" by recipients, reinforce the salience of distinctions between taxpayers and beneficiaries, and prime stereotyped beliefs about the beneficiary class and whether they are worthy. Among those who hold a strong belief in a "just world," debates about who should receive benefits might cue the cognitive schema by which they make sense of persistent poverty by attributing blame to people who cannot seem to overcome it. ${ }^{176}$

Universal social insurance programs are by definition organized around a common risk from which they buffer pooled participants. Thus, for example, the need for income continuity when illness or caregiving disrupt work can be understood not as a poor people's problem, nor an old people's problem, nor a young family's problem,

173 Bo Rothstein, Just Institutions Matter: The Moral and Political Logic of the Universal Welfare State 158-60 (1998).

174 Id. at 159.

175 Id. at 160.

176 See Larsen, note 96, at 152 (arguing that selective benefits make more salient who benefits from the welfare state and who loses). 
nor a women's problem-but as a basic human challenge everyone faces, if not now, then some time in their lives. ${ }^{177}$ Insofar as redistribution might occur within universal programs, such redistribution would alleviate some of the burden on means-tested programs to combat poverty, and thus produce the double effect of also reducing the number of people vulnerable to categorization as "undeserving" in the collective imagination.

The state of the economy can also serve as a frame that triggers context-dependent beliefs about deservingness. Support for welfare spending tends to increase in economic recessions. ${ }^{178}$ This may be because more people start to feel as though they could end up needing public support, but beliefs about deservingness are likely also at play. ${ }^{179}$ When the economy prospers, people tend to blame poverty on the poor for not trying hard enough and when times are bad, people are more likely to attribute poverty to factors beyond people's control. ${ }^{180}$ Emphasizing the current widespread perception of a need for buffers against larger structural forces that might lead to economic insecurity-the recent financial crisis would be an excellent example-can draw the perceiver's attention away from vulnerable groups who potentially might be seen to have brought misfortune upon themselves, and direct it towards vulnerabilities that cut across class, race, and generation.

\section{An Illustration: Paid Family Leave in California}

Let me turn, then, to an illustration based on current policy developments that might sharpen the focus: paid family leave policies. I should say at the outset that $\mathbf{I}$ do not present this illustration as a sample "success story" or even as evidence that my thesis is correct. On the contrary, I believe (and we should predict) that it is too early to know. But the case represents an opportunity to make some early observations and isolate a number of research questions that would

177 In this vein, the disability rights movement has embraced the concept of the "temporarily able-bodied": We are all going to be disabled eventually. Martha Minow, Making All the Difference: Inclusion, Exclusion, and American Law 341 (1990) ("we able-bodied persons are only temporarily able-bodied; we could all at some time return to the position of dependence on others"); David Ferleger \& Penelope A. Boyd, Anti-Institutionalization: The Promise of the Pennhurst Case, 31 Stan. L. Rev. 717, 742 n.107 (1979) (reporting that disabled persons refer to the nondisabled with the acronym "TAP," which stands for "Temporarily Able-bodied Persons"); see also Martha Albertson Fineman, The Vulnerable Subject: Anchoring Equality in the Human Condition, 20 Yale J.L. \& Feminism 1, 17 (arguing that mobilizing around shared vulnerability across race and gender lines can be a way to build coalitions for combating discrimination).

178 Gilens, note 139 , at $45-52$.

179 Id. at $49-50$.

180 Id. at $48-50$. 
help us in evaluating the strength of the universality-redistribution thesis.

There is widespread consensus that balancing work and familyand in particular, managing work interruptions to care for members of one's family-is one of the central challenges of contemporary American life. The major federal policy in this realm, the Family and Medical Leave Act of 1993 (FMLA), ${ }^{181}$ grants up to twelve weeks of jobprotected leave per year for workers who must take time off due to a serious health condition, to care for a newborn, or to care for a family member who has a serious health condition. ${ }^{182}$ The FMLA does not include wage replacement. In 2010 , only $10 \%$ of private industry workers had access to paid family leave, ${ }^{183}$ and about $20 \%$ had a limited number of "sick days" per year that could be used for family care. ${ }^{184}$

A common criticism of the FMLA is that many lower-income workers cannot take family leave, either because they are not covered by the Act (which covers only about half of workers), or because they do not have sufficient savings to afford a needed leave. ${ }^{185}$ Most of the workers who do take leave are those who have employer-based wage replacement, and these leave-takers are more educated, have higher incomes, and are more likely to earn a salary (as opposed to hourly wage) than those who do not take leave. Many workers who need leave do not take it or cut it short, most commonly citing that they cannot afford to suspend earnings. ${ }^{186}$ For years, scholars and policy

181 Family and Medical Leave Act of 1933, Pub L. No. 103-3, 107 Stat. 6 (codified as amended in scattered sections of 29 U.S.C. and 5 U.S.C.).

18229 U.S.C. $\$ 2612$ (a)(1) (2006 \& Supp. 2009).

183 Bureau of Labor Statistics, U.S. Dep't of Labor, Employee Benefits Survey, Leave Benefits: Access Data Table (Mar. 2010), http://www.bls.gov/ncs/ebs/benefits/2010/owner ship/private/table21a.htm.

184 About $62 \%$ of private industry workers are eligible for sick leave through private employer plans, id., and an earlier study estimated that about $30 \%$ of workers have sick leave plans that permit sick leave to be used for family care. Vicky Lovell, Inst. for Women's Pol'y Research, No Time to Be Sick: Why Everyone Suffers When Workers Don't Have Paid Sick Leave, 9 tbl.3 (2004), http://www.iwpr.org/pdf/B242.pdf.

185 Gillian Lester, A Defense of Paid Family Leave, 28 Harv. J.L. Gender 1, 3 (2005); Ann O'Leary, How Family Leave Laws Left Out Low-Income Workers, 28 Berkeley. J. Emp. Lab. L. 1, 41-46 (2007).

186 Roughly $13 \%$ of employees polled in a 2001 survey who reported needing to take a leave did not take it. U.S. Dep't of Labor, FMLA Survey: Balancing the Needs of Families and Employers 2-2 tbl.2.1, 2-14 tbl.2.14 (2001), available at http://www.dol.gov/asp/ archive/reports/fmla/chapter2.pdf. In a 2003 survey of employed workers in California, $18.4 \%$ reported that at some point in the previous five years, they did not take a leave despite having wanted to do so. Ruth Milkman \& Eileen Appelbaum, Paid Family Leave in California: New Research Findings, The State of California Labor 2004, at 45, 57-58, available at http://www.irle.ucla.edu/research/scl/pdf04/scl2004ch2.pdf. 
advocates have been advocating public provision of wage replacement for family leave on a variety of normative grounds. ${ }^{187}$

Recently, there have been some major policy developments in this domain. Since 1994, three states have enacted universal paid family leave programs based on a social insurance model, ${ }^{188}$ and nine other states are currently considering such proposals. ${ }^{189}$ There are also several federal bills or initiatives under debate. ${ }^{190}$ These new policy developments can serve as a natural laboratory for studying the limits and possibilities for redistribution within their boundaries. California's program is the furthest along and thus most helpful for purposes of illustration.

California's Family Temporary Disability Insurance (FTDI) replaces $55 \%$ of the wages, for up to six weeks in any twelve-month period, of workers who must take time off to care for seriously ill family members or bond with a new child. ${ }^{191}$ The benefit covers virtually all private-sector workers. ${ }^{192}$ There is a floor on benefits of about $\$ 50$

187 Some recent examples are Ariel Meysam Ayanna, Aggressive Parental Leave Incentivizing: A Statutory Proposal Toward Gender Equalization in the Workplace, 9 U. Penn. J. Labor \& Emp. L. 293 (2007); Lisa M. Keels, Family and Medical Leave Act, 7 Geo. J. Gender \& L. 1043, 1052 (2006). Workplace Flexibility 2010 \& Berkeley Ctr. on Health, Econ. \& Family Sec., Family Security Insurance: A New Foundation for Economic Security (2010), available at http://familysecurityinsurance.org/. For a more comprehensive review, see Lester, note 185 , at 1, 18-33.

188 Cal. Unempl. Ins. Code $\S \S 3300-3306$ (West 2008); Wash. Rev. Code $\S 49.86$ (2008); 2008 N.J. Sess. Law Serv. ch. 17 (West).

189 H.B. 2594, 50th Leg., Reg. Sess. (Ariz. 2011)(Arizona); H.B. 2258, 25th Leg., Reg. Sess. (Haw. 2010)(Hawaii); S.B. 71, 186 Gen. Court (Mass. 2009)(Massachusetts); H.B. 1940, 95th Gen. Assemb., 2nd Reg. Sess. (Mo. 2010)(Missouri); H.B. 661, 2009 Leg., 161st Sess. (N.H. 2009)(New Hampshire); S.B. 5791, 232d Leg. Sess. (N.Y. 2009)(New York); H.B. 1558, 193d Gen. Assemb., Reg. Sess. (Pa. 2009)(Pennsylvania); H.B. 1057, 81st Leg., Reg. Sess. (Tex. 2009)(Texas); H.B. 672, 2009-2010 Leg. Sess. (Va. 2010)(Virginia); see also Nat'l P'ship for Women \& Families, 2010 State Action on Paid Family and Medical Leave (2010), available at http://www.nationalpartnership.org/site/DocServer/Paid_Leave_Track ing.pdf?docID $=1921$.

190 Family Income to Respond to Significant Transitions (FIRST) Act, H.R. 2339, 111th Cong. (2009); The Family Leave Insurance Act of 2009, H.R. 1723, 111th Cong. (2009); The Family Leave Insurance Act of 2007, S. 1681, 110th Cong. $\$ 306$ (2007). In addition, President Obama's Fiscal Year 2012 budget proposal for the Department of Labor includes a \$23 million "State Paid Leave Fund" to assist states with the start-up costs associated with developing paid leave programs. Dep't of Labor, FY 2012 Congressional Budget Justification, Employment and Training Administration, available at http://www.dol.gov/dol budget/2012/PDF/CBJ-2012-V1-03.pdf.

191 Cal. Unemp. Ins. Code $\$ 3301$ (a)-(d) (West 2008). Leaves to care for ill domestic partners are included.

192 To be eligible, a worker need only to have earned $\$ 300$ or more in any quarter during the 5-17 months prior to filing a claim. Employer size is irrelevant. Cal. Unemp. Ins. Code $\S 2610,2652$. 
per week, and a ceiling of about $\$ 1000$ per week. ${ }^{193}$ Participation is mandatory, although an employer may opt out of the program if it offers a voluntary plan that is more generous than what the statute requires. The benefit is financed by a payroll tax on employees up to a set limit (\$93,316 for 2011). ${ }^{194}$ The incremental tax imposed on each employee to finance the benefit averages about 90 cents per week. ${ }^{195}$

The question for present purposes is whether we might use this case to focus our analysis of the influence of the psychological phenomena I described earlier-reciprocity, groupism, and framing-and their potential for generating public support, and ultimately, for achieving redistribution. Consider first the process by which public support developed around the proposal. Based on the earlier analysis, one could hypothesize that support for universal provision might be actuated around the intense constraints that poor, middle-class, and wealthy workers alike face in balancing work and family. For low-income workers, availability of benefits is limited or non-existent. For middleand high-income workers, the availability of private benefits through the workplace is increasingly precarious. Possibilities are rife for common cause across income groups in support of paid leave insofar as it promises to offer material resources for reconciling work and family.

In the period leading up to passage of the California legislation, active constituencies on both sides of the issue worked to frame the issue from their own perspective and to communicate this message to the press and the public. The Berkeley Media Studies Group analyzed the content of approximately 300 news media pieces (television, newspapers, magazines, and radio) covering California Senate Bill 1661 as debate intensified in the period surrounding the Governor's signing the bill, from June 1 through October 31, 2002.196 The re-

193 For 2010 , weekly benefits ranged between $\$ 50$ and $\$ 987$. Emp. Dev. Dep’t, Disability Insurance Benefits, http://www.edd.ca.gov/Disability/DI_Benefit_Amounts.htm (last visited Feb. 2, 2011).

194 Empl. Dev. Dep't, SDI Contribution Rates, http://www.edd.ca.gov/Disability/SDI_ Contribution_Rates.htm (last visited Feb. 2, 2011); Emp. Dev. Dep't, State Disability Insurance-Quick Statistics (2011), available at http://www.edd.ca.gov/About_EDD/pdf/ qsdi-Taxable $\% 20$ Wage\% 20 Ceiling.pdf (providing a chart of the taxable wage ceiling from 1998-2010).

195 Because the tax that finances the benefit is part of the tax that finances state shortterm disability benefits, it is hard to know exactly the size of the incremental payroll tax required to finance the benefit. In 2010, SDI (including FTDI) cost an average California employee about $\$ 9$ per week. Emp. Dev. Dep't, Average SDI Contributions (2010), available at http://www.edd.ca.gov/about_edd/pdf/qsdi-Avg_SDI_Contribution.pdf. FTDI claims account for about $10 \%$ of total SDI benefit expenditures. My rough estimate assumes that the portion of the tax required to finance the benefit is directly proportional to expenditures on the new program.

196 Making the Case for Paid Family Leave: How California's Landmark Law Was Framed in the News (Berkeley Media Studies Grp., Berkeley, Cal.), Nov. 2003, available at http://www.bmsg.org/pdfs/Issue14.pdf. 
searchers identified a number of different "frames" that were used to communicate the story, and counted their frequency of appearance. ${ }^{197}$

They identified six frames supportive of the bill: "Caring family, bonding moms" (which appeared in $69 \%$ percent of all media pieces), emphasizing the importance of giving both men and women the opportunity to care for loved ones; 198 "Balancing work and family" (41\%), emphasizing painful conflict between family and job;199 "Business wins too" $(27 \%)$, suggesting that paid family leave will help businesses profit;200 "Make family leave real" $(17 \%)$, decrying FMLA as "a mirage" that most employees cannot afford to use;201 "Corporate family values" ( $9 \%)$, emphasizing that corporations have duties to families and communities beyond (or despite) their primary goal to make a profit; ${ }^{202}$ and Competitive advantage $(6 \%)$, suggesting that paid family leave benefits the state as a whole. ${ }^{203}$

Opposing frames were "Unfair burden" (59\%), an emotional appeal to the plight of struggling businesses; 204 "Competitive disadvantage" $(30 \%)$, invoking an image of California losing jobs; 205 "Tax on jobs" $(29 \%)$, invoking the idea that the law imposes an unfair tax on employees because they cannot opt out; ${ }^{206}$ and "Nanny state/slippery slope" (24\%), a libertarian message that this legislation puts California on a slippery slope to a European-style paternalistic welfare state. ${ }^{207}$

It is noteworthy that the supportive frames most frequently invoked by the media used universalizing themes of family love and care, and painful conflict between being a good worker and a good family member: partner, son, or daughter. The supportive frame that emphasized economic inequality was distinctly less prevalent, perhaps reflecting a judgment on the part of media advocates that a "help for the poor" message would not be as effective in generating public support. The opposing frame that appeared most frequently highlighted the plight of small business. Although the "nanny state" imagery invoked least frequently suggests that opponents had at least some reason to believe that segments of the public would respond to the threat of a "socialized" welfare state, absent were frames relating to irresponsibility, de-

\footnotetext{
197 Id. at 6-10.

198 Id. at 6.

199 Id. at 6-7.

200 Id. at 7.

201 Id. at 7-8.

202 Id. at 8.

203 Id.

204 Id. at 9.

205 Id.

206 Id. at 10.

207 Id.
} 
pendency, or blameworthiness of people likely to benefit from the program. Although much of the impetus for the legislation was concern about the economic struggles of those who lack savings or employer-based benefits, economic inequality did not become an organizing schema for public debate. Similarly, concepts of "deservingness" did not play any role, contrary to the suggestion of researchers Martin Gilens and Shanto Iyengar that they often do in debates about means-tested anti-poverty programs. ${ }^{208}$ Future research might investigate whether the media covered other family policies during the same time period in California that proposed more direct targeting of poor populations. If so, it would be useful to see whether "blame frames" 209 were more prevalent than they were during the paid leave campaign.

The payroll tax financing, and broad contribution and eligibility requirements of FTDI might appeal to reciprocity norms in ways I discussed earlier. As explained in Part VI, however, reciprocity does not necessitate progressivity. The question remains open as to whether, over time, an increased tolerance for redistribution within the program might emerge. Currently, the tax is capped, making it regressive. Wage replacement is set at a fixed percentage of preleave earnings (although there is a floor - a very low one - and a ceiling that corresponds with the cap on the maximum wage base taxed). ${ }^{210}$ Thus the net tax and benefit structure is regressive.

Evidence that the public supported the program's creation with the belief that it would effectuate redistribution would be very powerful, but the success of my hypothesis that progressivity might emerge over time does not depend on it. Flat benefits would have made the net $\operatorname{tax} /$ benefit structure more progressive, but at the stage of initial introduction, wage-proportional benefits likely had more appeal for the politically engaged public that debated passage of the law. The relatively high maximum benefit cap makes the benefit nontrivial for middle- and higher-income workers. If a flat benefit had been used instead, its amount might have been capped at a relatively low level to assuage concerns that high replacement rates would lead to moral hazard at the lowest wage levels. The resulting benefit might have been too low to generate significant public support. ${ }^{211}$ It remains to

208 See notes $146-49$ and the accompanying text.

209 I borrow this term from Hanson \& Hanson, note 151.

210 Emp. Dev. Dep't, Disability Insurance and Paid Family Leave Weekly Benefit Amounts in Dollar Increments (2010), available at http://www.edd.ca.gov/pdf_pub_ctr/ de2589.pdf.

211 For example, implementation of the Washington state law is stalled because there has been difficulty in agreeing on a funding mechanism. Some have speculated that at least part of the difficulty is the unwillingness of the public to pay the proposed payroll tax in 
be seen whether, over time, there is the potential (or the will among political elites) for making the tax-to-benefit ratio more progressiveperhaps $80 \%$ wage replacement for those in the lowest quintile of earnings, $70 \%$ for the next quintile, and so forth-without raising significant resistance from participants concerned about unfairness or moral hazard due to excessive replacement rates. ${ }^{212}$

Public opinion polls conducted one year before, and one year after, passage of the legislation found strong majority support for the idea of paid leave. ${ }^{213}$ Large majorities favored paid leave in virtually every segment of the state's population, regardless of their gender, race or ethnicity, nativity, education, or political orientation. ${ }^{214}$ Questions that the survey did not illuminate-but which would aid the present endeavor-are whether support would change if respondents were asked whether and how much they would be willing to pay to create such a program, in what form of taxation, and whether and what ways their support might vary depending on whether benefits were flat, scaled to income, or graduated depending on income. It would be possible to design a survey that raised these and other questions designed to illuminate participants' "tolerance for redistribution."

Whether the program might achieve income redistribution by virtue of cross-subsidization within the risk pool is more complex, but also a worthy subject for research. Assuming the mandated risk pool incorporates low-income workers who would be excluded from private coverage, if low-income participants were to make relatively more use of the program than higher income workers, there might be an effective transfer of resources between high- and low-income participants.

The possibility for this route to progressivity, however, would depend on take-up by low-income workers. Early polling data suggest that take-up by low-income workers is disproportionately low. ${ }^{215}$ The

the absence of more generous benefits. Caroline McConnell, Washington Stumbles Towards Landmark Paid Family Leave, Crosscut (Apr. 4, 2008), http://crosscut.com/2008/04/ 04/social-services/13118/Washington-stumbles-toward-landmark-paid-family-leave/. An amendment to the original Act was adopted in 2009 delaying the start date of the program to October 1, 2012. S.B. 6158, 61st Leg., Reg. Sess. (Wash. 2009); Wash Rev. Code $\$ 49.86 .030$ (West 2008 \& Supp. 2010).

212 There is currently a one-week waiting period, which operates like a deductible and thus reduces moral hazard. Emp. Dev. Dep't, FAQs for Paid Family Leave, http://www. edd.ca.gov/Disability/FAQs_for_Paid_Family_Leave.htm (last visited Mar. 21, 2011).

${ }^{213}$ Milkman \& Appelbaum, note 186, at 52 (reporting results of 2003 survey in which $84.9 \%$ of respondents favored the idea of paid leave when asked, "Do you favor or oppose the idea of a law that guarantees that eligible workers receive a certain portion of their pay when they take family or medical leave?" and 2001-02 survey in which $78 \%$ favored the idea).

214 Id. at 53.

215 A 2007 California Senate report found that workers earning less than $\$ 12,000$ per year made disproportionately few FTDI claims. Rona Levine Sheriff, Cal. Senate Office of Research, Balancing Work and Family 7-10 (2007), available at http://www.sor.govof 
reason for this is uncertain, but one possible explanation is lack of public awareness. A 2008-09 survey of employed California workers who had experienced a life event that the program was designed to cover (a new baby or seriously ill family member) found that only about half $(48.6 \%)$ were aware the program existed ${ }^{216}$ and respondents from low-income households (households earning less than $\$ 30,000)$ were about half as likely as other respondents to be aware of the program. ${ }^{217}$ Another possible reason for lack of take-up among low-income workers is that for workers whose earnings just meet monthly expenses, the $55 \%$ wage replacement rate is too low as a practical matter to enable leave-taking. ${ }^{218} \mathrm{~A}$ third explanation is that many low-income workers are not covered by FMLA, and in the absence of job protection, some are afraid that if they take a leave they will lose their jobs. ${ }^{219}$ With $96 \%$ of California firms having less than fifty employees, roughly $40 \%$ of workers who are eligible for FTDI are ineligible for job restoration rights under the FMLA. ${ }^{220}$

While the constraints on low-wage workers may be extreme, analogous constraints are hardly absent for middle-class workers. Many middle income workers-not just low-income workers-lack access to private policies to replace wages during family leaves, and operate on family budgets that produce minimal savings and minimal discretionary income. ${ }^{221}$ Thus the practical challenge of taking a leave for more than a few days at $55 \%$ wage replacement may touch a nerve across income groups. Will middle-class workers-even if they have no particular concern for their low-income compatriots-feel the impetus to advocate for more generous benefits, such that all boats may rise? This remains to be seen. My analysis suggests that public advocacy efforts for improvements to the program over time might do well to emphasize the importance of the issue for all Californians, not just the poor.

fice3.com/vertical/Sites/\%7B3BDD1595-792B-4D20-8D44-626EF05648C7\%7D/uploads/ \%7B76AE4BE5-6C7B-4FEE-922C-F2FED1DB376C\%7D.PDF.

216 Eileen Appelbaum \& Ruth Milkman, Leaves that Pay: Employer and Worker Experiences with Paid Family Leave in California 13 (2011) available at http://www.cepr.net/ documents/publications/paid-family-leave-1-2011.pdf.

217 Id.

218 Id. at 28 (discussing reasons given by respondents who did not take leaves even though they believed they were eligible).

219 Id.

220 Author's calculations, based on data on employer-size distribution in Labor Mkt. Info. Div., Emp. Dev. Dep't, Distribution of California Employment (2009), available at http://www.calmis.ca.gov/file/indsize/Chart_SOB09_4.pdf.

221 Elizabeth Warren \& Amelia Warren Tyagi, The Two-Income Trap: Why MiddleClass Mothers \& Fathers Are Going Broke 8-11 (2003) (discussing decline over the past several decades in the level of discretionary income available to middle-class families and the resulting lack of financial buffer in the event of unexpected income interruption). 
A related issue is the extent to which the law will crowd-out (or crowd-in) private paid leave policies, and if so, what distributional effects this might have. As discussed earlier, if a state mandate crowds out existing provision, social welfare may or may not decline for those who would have had access to private-employer benefits in the absence of the mandate (it would depend on the comparative cost and quality of the old and new benefits)..$^{222}$ Arguably, though, the broader the cross-section of the public that comes to rely on the FTDI program for paid leave, the stronger the impetus for mobilizing around program quality. The converse phenomenon-"crowd-in"-is also possible. The passage of the law may lead employers that wish to be "high road" employers to adopt policies that exceed the minimum requirements of the statute. ${ }^{223}$ If this were to happen, it could redound to the benefit of a broad cross-section of workers, or-conversely-it could mean that a quality gap persists between "low" and "high" road policies, leaving little impetus for workers who enjoy high-road policies to alter the new status quo. It is too early to gauge the presence or valence of crowding by FTDI and any distributional impact such crowding might have. Once again, however, the presence or absence of crowding is a testable phenomenon, and a research question that could shed light on the plausibility of my thesis.

A final comment about the California paid leave law is that it seems likely that the prior existence in California of a temporary disability social insurance program ${ }^{224}$-something that exists in only five states and Puerto Rico 225 - smoothed the way for FTDI. FTDI operated as an incremental expansion of the temporary disability insurance program. Perhaps the very possibility of creating similar programs in other states (assuming we were persuaded of their value) is tenuous given the rarity of a suitable preexisting social insurance apparatus (and normative mentality) on which to build. At the same time, we

222 See text accompanying notes 52-53.

223 See, e.g., Wen-Jui Han \& Jane Waldfogel, Parental Leave: The Impact of Recent Legislation on Parents' Leave Taking, 40 Demography 191, 196 (2003). This study of the impact of unpaid leave mandates in state and federal law found an increase in the likelihood and duration of leaves taken by workers who were not beneficiaries of the mandate. Id. The authors speculate that this reflects the following spillover effect: As the laws became more generous, so too did firms covered by the laws, extending benefits even to workers they were not required to cover. Id; see also O'Leary, note 185, at 38 (reporting federal survey data showing an increase in unpaid leave policies within exempt firms following passage of FMLA and speculating that the statute had a positive norm-creation effect).

224 Act of Mar. 5, 1946, ch. 81, §100,1946 Cal. Stat. 101, 103 (codified as amended at Cal. Unemp. Ins. Code § 2601) (West 1986 \& Supp. 2011).

225 See U.S. Dep't of Labor, Comparison of State Unemployment Laws, ch. 8 (2011), available at http://www.ows.doleta.gov/unemploy/uilawcompar/2009/disability.pdf (last visited Apr. 18, 2011). 
need not overstate the significance of the existing institutional structure. The program was not "slipped in under the radar" of an existing program. Californians were asked to pay a new tax on their earnings for a new, specific, purpose, a tradeoff about which the public debate was very explicit. Moreover, Washington State's similar paid leave legislation was created in the absence of any pre-existing similar social insurance scheme, suggesting that an existing TDI infrastructure-or mentality-was not essential. Instead, a more general emerging social norm favoring income security for family care might be evolving.

This raises a larger issue of the reality that windows for major social change require the alignment of contingencies that may be unique to each policy context. My argument suggests that the initial framing effects for the public of being "in this together" and minimizing the "otherness" of beneficiaries will be more likely to set the program on a positive trajectory for sustained public support. Therefore a progressively motivated social planner should endeavor to start with universal provision, even if initially not redistributional, building in greater progressivity over time. However, if as some scholars suggest, institutional "lock-in" makes existing policies sticky, there may be advantages to working for incremental change from within existing means-tested programs.

An example is the Children's Health Insurance (CHIP) program. The program authorizes states to subsidize enrollment in private health insurance plans for the children of low-income working parents. ${ }^{226}$ While originally targeted only at very poor families, ${ }^{227}$ President Obama signed legislation early in his presidency with the purpose of both increasing take-up by existing targeted populations and expanding eligibility, including enabling states to raise the eligibility threshold to include middle-income families. ${ }^{228}$ Notwithstanding the expansion into higher income groups, progressivity was built into the new eligibility requirements, so that poorer enrollees will still receive fuller coverage. It remains to be seen whether CHIP will expand still further. During the period of debate leading up to reauthorization, public opinion polls revealed support by a considerable majority for program expansion, but later polls saw support fall to a slimmer ma-

22642 U.S.C. § $1397 \mathrm{aa}-\mathrm{mm}$ (2006).

22742 U.S.C. $\$ 1397 \mathrm{bb}(\mathrm{a})(4)$ (2006) (requiring targeting of low-income children).

228 Children's Health Insurance Program Reauthorization Act of 2009, Pub. L. No. 1113, 123 Stat. 8 (2009); see also Kaiser Comm'n on Medicaid and the Uninsured, Key Facts: Children's Health Insurance Program Reauthorization Act of 2009 (2009) (explaining how the new legislation enables expanded coverage into higher income cohorts), available at http://www.kff.org/medicaid/upload/7863.pdf. 
jority. ${ }^{229}$ Moves to expand targeted benefits into less poor populations, especially if financing is non-contributory (that is, if it is funded by general revenues) run the risk of exacerbating social cleavages if public disagreements arise over "middle-class abuse" of the programs and "undeserving" beneficiaries. 230 There is some flavor of this sentiment in at least some of the recent public discourse surrounding a similar expansion of Medicaid as part of federal health care reform.231

To summarize this Part, one can speculate on a number of ways in which the motivational account developed in Part V could guide how we think about the design of social insurance institutions. I have offered the example of California's recently adopted paid leave insurance program to illustrate the process-with emphasis on the universalizing frame used by its advocates-that gave rise to a new program of social insurance in the country's most populous state, although it remains to be seen what trajectory it will take over time in terms of its progressivity. Although I do not offer other similarly detailed illustrations in this Article, paid leave is not the only area in which my argument may have salience. Other ideas or initiatives in recent years that would, to a greater or lesser degree, marshal universalism in the service of vertical redistribution include proposals for establishment of child development accounts, ${ }^{232}$ caretaker accounts, ${ }^{233}$

229 A national poll released in October 2007, when the matter was being debated, found that $65 \%$ of respondents favored reauthorization and expansion of CHIP. Nat'l Pub. Radio, Kaiser Family Found. \& Harvard Sch. of Pub. Health, Public Views on SCHIP Reauthorization 1 (2007), available at http://www.kff.org/kaiserpolls/upload/7704.pdf. Another poll by the same organization released in January 2009 showed $51 \%$ support for increased spending on CHIP. Kaiser Family Found. \& Harvard Sch. of Pub. Health, The Public's Health Care Agenda for the New President and Congress 5 (2009), available at http://www.kff.org/kaiserpolls/upload/7853.pdf.

230 See, e.g., Colleen M. Grogan \& Eric M. Patashnick, Universalism Within Targeting: Nursing Home Care, the Middle Class, and the Politics of the Medicaid Program, 77 Soc. Serv. Rev. 51, 61, 65 (2003) (describing successful rhetorical appeals of Clinton administration to the needs of "middle class working people" to resist conservative Medicaid retrenchment initiatives, but simultaneous ambivalence of public and political elites about the use of Medicaid by relatively well-off people); see also Soltermann, note 3, (arguing against middle-class inclusion in Medicaid).

231 See, e.g., Emily Ramshaw \& Marilyn Serafini, Battle Lines Drawn Over Medicaid in Texas, N.Y. Times, Nov. 12, 2010, at A21. The authors describe debates in several states over whether to exercise their right to opt out of a provision in the Patient Protection and Affordable Care Act [ACA] that would require states to expand Medicaid rolls in exchange for a portion of available federal subsidies. State Representative Warren Chisum, of Pampa, Texas, is quoted as saying, "If people are in superbad poverty, that's one thing, [but] it breaks my heart when there's someone who smokes, and who stays drunk half the time, and we're supposed to provide their health care."

232 Bruce Ackerman \& Anne Alstott, The Stakeholder Society 4-12, 155-77 (1999) (proposing $\$ 80,000$ "stakeholder grants" for all Americans upon turning eighteen, emphasizing the importance of their universality to the creation of national community, and financed by a progressive tax); Deborah Adams, Ray Boshara, Margaret Clancy, Reid Cramer, Bob Friedman, Rochelle Howard, Karol Krotki, Ellen Marks, Lisa Mensah, Bryan Rhodes, 
the movement for universal preschools, ${ }^{234}$ and some varieties of the school choice movement. ${ }^{235}$ These examples do not follow the conventional social insurance model to which I have tailored my arguments, but there is a shared intuition in the core principles that drive their combination of universal access and progressive financing. ${ }^{236}$

\section{Welfare State Universalism and "Social Solidarity"}

The analysis to this point has argued that prudent design of social protections against economic insecurity-in particular, a preference for universalist schemes that satisfy reciprocity norms and reduce the salience of social cleavages-can reduce barriers to creation of social programs that have the potential to achieve redistribution, whether or not they start out that way. I further speculate on the possibility that

Carl Rist, Edward Scanlon, Leigh Tivol, Trina Williams Shanks \& Robert Zager, Lessons from SEED: A National Demonstration of Child Development Accounts (Michael Sherraden \& Julia Stevens eds., Sept. 2010), available at http://assets.newamerica.net/sites/ newamerica.net/files/policydocs/Lessons_from_SEED.pdf (describing various recent U.S. experiments with universal, progressive, trust funds for children that can be drawn upon when the child turns eighteen for purposes of education, buying a home, or creating a retirement account); David Kirp, Kids First: Five Big Ideas for Transforming Children's Lives and America's Future 178-82 (2011) (advocating universal, progressive, child development accounts and discussing initiatives in Maine, Oklahoma, and the United Kingdom).

233 Anne L. Alstott, No Exit: What Parents Owe Their Children and What Society Owes Parents 95-98 (2004) (proposing state-provided caretaker accounts for all parents, with particular emphasis on the critical role of the rejection of mearis-testing as an allocation mechanism on grounds of liberal autonomy ideals, administrative efficiency, and political pragmatism).

${ }^{234}$ See, e.g., Timothy J. Bartik, Distributional Effects of Early Childhood Programs and Business Incentives and their Implications for Policy (Upjohn Inst., Working Paper No. 09151,2009 ) (empirical analysis of projected distributional effects of targeted versus universal state-funded preschools).

235 See, e.g., Scott Franklin Abernathy, School Choice and the Future of American Democracy 111-13 (2005) (proposing state provision of universal scholarships for all schoolage children, financed by general revenues, to be used only for public school education, and with a prohibition on the ability of any school to supplement resources by raising money within the district through property taxes or private donations).

236 Another obvious area in which my analysis would seem relevant is in the recently adopted Patient Protection and Affordable Care Act, Pub. L. No. 111-148, 124 Stat. 119 (2010). The health care debate is complicated because it combines questions about universal versus means-tested provision with questions about the state versus private actors as the service provider of medical care. A stable large majority ( $80 \%)$ of Americans believe that health care should be a wholly or partially collective responsibility. Mark Schlesinger \& Jacob S. Hacker, Secret Weapon: The "New" Medicare as a Route to Health Security, 32 J. Health Pol., Pol'y \& L. 247, 252 fig.1 (citing data over a twenty-five-year period from the General Social Survey). But Americans are deeply divided over the question of whether the public sector or the private sector is the best agent for actual provision of services. Id. at 254-56. This public-private divide interacts with the universalism versus targeting debate in a way that makes it more difficult to discern what mix of factors is at play in shaping public opinion. In light of this cross-cutting dynamic, I have largely sidestepped the health care debate in my analysis notwithstanding its policy currency. 
universalist design features will smooth the way for increased program progressivity over time. The exercise, in essence, is one of creating the conditions for the altruistic elements of people's rational utility function to dominate the self-interested elements. It is an optimizing exercise of sorts, assuming a prior normative commitment to achieving redistribution.

The question in this Part is whether it is possible to do more than this-to create conditions that might alter people's initial predilections. Might some kinds of welfare institutions alter the ratio of selfregarding to other-regarding impulses that comprise one's rational utility function? It is possible-and many before me have arguedthat a kind of preference-shaping "social learning" might occur as a consequence of the prevailing institutional context. Could universalistic social insurance against common social risks be one such context?

The notion that institutional form might generate social preferences is more familiar within sociology, and economics in the institutional vein, than it is within the mainstream public finance theory that dominates U.S. welfare policy. ${ }^{237}$ The mid-twentieth century British social theorists Richard Titmuss, T.H. Marshall, and R.H. Tawney theorized a linkage between social bonds and broad-based government social provision. Titmuss argued that Britons' second-world war experience of a mass external threat created the psychological conditions-the recognition of shared fate and the need to attend to all citizens-for the creation of universalist social policy. ${ }^{238}$ In this account causality runs from an external shock, to the formation of solidarity, to the creation of welfare institutions that collectivize risk. ${ }^{239}$

Titmuss and contemporaries, however, also advanced a distinct justification for universalist provision based on the (potentially) stronger concept of social solidarity. Means-testing, Titmuss argued, weakens the bonds of society by drawing distinctions between the worthy who are self-sufficient and the unworthy who are not. ${ }^{240}$ T.H. Marshall,

237 Emile Durkheim famously asked "what bonds unite men to one another." Emile Durkheim on Institutional Analysis 205 (Mark Traugott ed., trans. 1978). One of Durkheim's principle preoccupations was the question whether laws by which society binds itself to cooperate are a manifestation of the moral impulse toward solidarity, or instead are generative of solidarity.

238 Richard M. Titmuss, War and Social Policy, in The Philosophy of Welfare: Selected Writings of Richard M. Titmuss 102, 111-12 (Brian Abel-Smith \& Kay Titmuss eds., 1987).

239 For a recent argument in a similar vein, see William P. Quigley, What Katrina Revealed, 2 Harv. L. \& Pol'y Rev. 361, 376-80 (2008) (arguing that the Katrina disaster, by making people recognize shared vulnerability, was a lightening rod for formation of social solidarity, and that this solidarity should in turn be marshaled in the service of advocating the creation or expansion of accountable public programs designed to support community rebuilding).

240 Richard M. Titmuss, Universal and Selective Social Services, in Philosophy of Welfare, note 238 , at $128,128-31$. 
elaborating on his concept of "social citizenship" in his famous lectures on "Citizenship and Social Class" defended universal welfare provision as follows:

What matters is that there is a general enrichment of the concrete substance of civilised life, a general reduction of risk and insecurity, an equalisation between the more and the less fortunate at all levels-between the healthy and the sick, the employed and the unemployed, the old and the active, the bachelor and the father of a large family. Equalisation is not so much between classes as between individuals within a population which is now treated for this purpose as though it were one class. . .

Even when benefits are paid in cash, this class fusion is outwardly expressed in the form of a new common experience. All learn what it means to have an insurance card that must be regularly stamped (by somebody), or to collect children's allowances or pensions from the post office..$^{241}$

Titmuss and Marshall were not simply positing that universalist social policy reflected solidarity; they distinctly argued that universalism could foster a normatively desirable perception of common experience, emphasizing mutual, rather than competing, interests of taxpayers and beneficiaries. ${ }^{242}$

Some contemporary U.S. scholars express a similar view. For example, Tom Baker argues that the design of insurance institutions can affect social attitudes, in particular the degree to which individuals facing risk feel social solidarity, in the form of mutual responsibility for one another. ${ }^{243}$ More tightly actuarial insurance-in which higherrisk participants are excluded-argues Baker, is less conducive to generating this kind of mutual responsibility. ${ }^{244}$ Deborah Stone argues that insurance (both private and public), because it pools risk within a community, reinforces norms of altruism, collective responsibility, and mutual aid. ${ }^{245}$ Citizens, she contends, cannot escape the implicit

241 Marshall, note 19, at 56.

242 Richard M. Titmuss, Social Welfare and the Art of Giving, in Philosophy of Welfare, note 238, at 113, 115-24; S.M. Miller, Introduction: The Legacy of Richard Titmuss, in Philosophy of Welfare, note 238, at 1, 13-14.

${ }^{243}$ E.g., Tom Baker, Risk, Insurance, and the Social Construction of Responsibility, in Embracing Risk: The Changing Culture of Insurance and Responsibility 33, 46 (Tom Baker \& Jonathan Simon eds., 2002) (design of insurance, particularly degree of actuarialism, crucial to the social construction of responsibility and social solidarity).

244 Id.

245 See, e.g., Deborah Stone, Beyond Moral Hazard: Insurance as Moral Opportunity, in Embracing Risk, note 243, at 52, 61-63 (2002). 
moral lesson of altruism and collective responsibility inherent in social insurance "no matter how much they chafe under mandatory participation." 246

A variant on this argument is that cross-class benefits may lead to social learning, as better-off people come to recognize their common humanity with others who share a common need for security against risk. ${ }^{247}$ Meredith Rosenthal and Norman Daniels make this kind of argument about the empathy-generating (as well as norm-setting) possibility of universal health insurance. They argue:

The attitudes people have toward seeking collective solutions to social problems are in part a product of the institutions that they encounter. People embedded in social insurance schemes tend to sustain attitudes of social solidarity, believing sharing risks is a social obligation. Of course, cultures with social insurance schemes may have had deeper commitment to social solidarity to start with, but the stability of these institutions over the long run in many countries suggests they help shape attitudes, as well. American commitment toward solidarity in our Social Security and Medicare schemes-the "third rail" of politics-may be sustained by the benefits produced by the collective sharing of risks. ${ }^{248}$

Skocpol uses similar arguments in defense of more universalistic social policy:

Universalistic policies would also change the attitudes of more privileged Americans, which returns us to the bedrock matter of broad and sustainable support for antipoverty policies .... If and when new public social policies begin to help American families from all social classes and all racial and ethnic groups to meet contingencies of ill health, job loss, and the challenges of balancing paid work and parental responsibilities, then a "kinder and gentler" political nation might actually emerge. With their own values and needs recognized through a revitalized public sector, larger numbers

246 Id. at 63; see also Jonathan Simon, The Ideological Effects of Actuarial Practices, 22 Law \& Soc'y Rev. 771 (1988).

247 See, e.g., Albert Weale, Equality, Social Solidarity and the Welfare State, 100 Ethics 473 (1990).

248 Meredith Rosenthal \& Norman Daniels, Beyond Competition: The Normative Implications of Consumer-Driven Health Plans, 31 J. Health Pol., Pol'y \& L. 671, 681-82 (2006); see also Tony Prosser, Regulation and Social Solidarity, 33 J. L. \& Soc'y 364, 383 (2006) (arguing for universal state provision of health and education services as a means of "regulating for social solidarity" and reducing social fragmentation). 
of middle-class American citizens would be prepared to go the extra mile for especially needy minorities. ${ }^{249}$

These theorists seem to suggest that universal provision can lead to more permanent social change through recognition of common humanity - a kind of empathy-generative social learning process. ${ }^{250}$ In all of these writings, however, the psychological mechanism by which this solidarity might emerge is only vaguely specified. How, exactly, would it work?

One hypothesis is that universal programs can lead to the social integration of middle-class and low-income people who physically interact through their involvement in a public program. This story has resonance in the context of something like public education, where public provision has doubtless reduced segregation as compared with an alternative, hypothetical world without public education. Face-toface interaction between children and adults whose economic, ethnic or racial, and neighborhood differences would otherwise erect social barriers might-notwithstanding its quasi-compulsory nature ${ }^{251}$-facilitate friendships, trust, and empathy through cooperative involvement in school events and collaboration around educational values and policy. We might recast this story about face-to-face interaction through schools (or health clinics, nursing homes, or childcare facilities, for that matter) in terms of its cognitive foundations. Provision of services on equal terms to the poor and nonpoor so that people are physically using the same services might diminish the perception of group distance. A diminished perception of group status might facilitate deeper fellow-feeling between citizens. Certain other aspects of public life resonate along this dimension-jury service, military service, market employment, some aspects of political participation. ${ }^{252}$

The puzzle is what relevance (if any) this hypothesis holds for public insurance. Some, to be sure, but the case would seem uneasy. Social insurance programs do not, for the most part, require any face-toface interaction between citizens. Although some programs require

\footnotetext{
249 Skocpol, note 84, at 272 .

250 See also John J. Rodger, Social Solidarity, Welfare and Post-Emotionalism, 32 J. Soc. Pol'y 403, 412-13 (2003) (arguing that the weakening of state involvement in welfare policy that promotes reciprocal social and economic dependence between all social classes may lead to social divisions and "post-emotional" society in which the plight of the disadvantaged is manifested intellectually rather than with sincere emotion or empathy).

251 I say quasi-compulsory because independent schools are an option for some, but not all, citizens.

252 I do not mean to suggest that face-to-face interaction across group lines will always lead to harmony and solidarity between groups, but rather that there is genuine potential for such integration to occur. For a thoughtful analysis of how compulsory workplace affiliations might instill intergroup social ties, see Cynthia Estlund, Working Together: How Workplace Bonds Strengthen a Diverse Democracy 74-83 (2003).
} 
beneficiaries to work with someone from the administrative agency (caseworker, unemployment counselor), this is not the same as faceto-face interaction between participants in the pool of contributors and beneficiaries. Technological change has meant that Marshall's ideal of fellowship borne of the shared necessity of going to the post office to collect a pension check is no longer a descriptive reality. Cash transfers can happen through direct deposit in one's bank account. Still, even the relatively interpersonal arms-length context of universal social insurance can give rise to forms of community. ${ }^{253}$

To again situate this argument within the cognitive phenomena this Article has described, one could imagine a process by which preference-altering social learning could happen in connection with participation in a program of universal welfare benefits. This process would go beyond simply "institutionally framing" social choices to encourage the dominance of people's other-regarding over self-regarding preferences from within some fixed underlying mix of preferences that comprises their utility function. It might be possible to alter their dispositions - change the "mix."

Suppose a universal social insurance program is establishedlargely fueled by median voters' self-interested motives. Certain reciprocity features are built into the program to facilitate trust and encourage buy-in: contribution requirements and selective mechanisms to regulate over-use. Suppose the system works: People see ways in which the program offers common security for themselves and others who occupy different social positions. People recognize improvements in overall social conditions that they associate with the program and come to more fully recognize their value. People's confidence in the program increases. Feeling this greater confidence, they feel more unity with other participants in their collective stewardship of the project. In this context, the salience of common group status with other participants as beneficiaries and stewards of the program dominates other aspects of their identity. Their judgment of the fairness of the distributional aspects of the program feels different now-not simply because of how their preferences are "cued" but because they feel they have learned something about the legitimacy of the program and other participants. The prospect of building more progressivity into

253 See Andrew Mason, Community, Solidarity and Belonging: Levels of Community and their Normative Significance 27-30, 38-40 (2000) (describing what he calls a "moralized concept of community" involving mutual concern among members and absence of exploitation, and yet not requiring face-to-face interaction, an example of which might be a welfare state funded through compulsory taxation); Jeff Dayton-Johnson, Social Cohesion and Economic Prosperity 132-35 (2001) (arguing that social insurance, as a collective act by citizens in protecting each other against risks, can bind participants to each other, generate a feeling of belonging, and generate social cohesion). 
the program does not seem unfair, and perhaps the prospect of expanding the range of programs that collectivize risk and redistribute income does not seem as threatening as it once did.

All of these things are possible. True, the story could unfold differently-public confidence could erode if a program were poorly designed or managed. My point is not to say that universal social insurance will always and inevitably lead to the evolution of more altruistic social preferences. But I have traced a plausible process by which it could.

\section{Conclusion}

In this Article, I have drawn a connection between institutionalist theories from sociology and political science as to why universalistic welfare policy might accomplish more redistribution than selective policy, and research in economics and psychology on the complexity of motives, in particular on the conditions under which people are willing to support redistribution. I do not claim that other explanations-cultural forces, racial legacies, material self-interest, institutional "lock-in"-have no explanatory power. On the contrary, it is plausible that each of these explanations does some work, and it is hard to speculate on their relative weight.

My argument is simply that phenomena operating at the cognitive level might also do significant work: Namely, welfare institutions designed around more universal distribution of benefits might serve as an "institutional frame" that increases support for-or at least reduces opposition to-redistribution within a universal scheme. It might do so by reinforcing reciprocity norms, reducing the salience of in-group favoritism along class and race lines, and by reducing the scope of public debate about the distinction between "deserving" and "undeserving" beneficiaries of public aid. More ambitiously, but also more speculatively, I conjecture that more universalist institutions for managing common social risks might establish the foundations for social learning that alters preferences more permanently over time.

Despite the necessarily tentative nature of my analysis, the intersection between positive political theory, behavioral science, and theories of social solidarity is an important and neglected area of inquiry. At the very least, this Article has aimed to increase awareness of its possibilities for fruitful application to social policy design. 
